https://helda.helsinki.fi

\title{
How does varying water supply affect oxygen isotope variations in needles and tree rings of Scots pine?
}

\section{Timofeeva, Galina}

2020

Timofeeva , G, Treydte , K, Bugmann , H, Salmon , Y, Rigling , A , Schaub , M , Vollenweider, P , Siegwolf, R \& Saurer, M 2020 , ' How does varying water supply affect oxygen isotope variations in needles and tree rings of Scots pine? ' , Tree Physiology, vol. 40 , no. 10 , pp. 1366-1380 . https://doi.org/10.1093/treephys/tpaa082

http://hdl.handle.net/10138/336580

https://doi.org/10.1093/treephys/tpaa082

acceptedVersion

Downloaded from Helda, University of Helsinki institutional repository.

This is an electronic reprint of the original article.

This reprint may differ from the original in pagination and typographic detail.

Please cite the original version. 
1 Running head: Oxygen isotope variations in Scots pine

2 How does varying water supply affect oxygen isotope variations in nee3 dles and tree rings of Scots pine?

4

5 Galina Timofeeva ${ }^{1,2,3}$, Kerstin Treydte ${ }^{2}$, Harald Bugmann ${ }^{3}$, Yann Salmon ${ }^{4,5}$, Andreas

6 Rigling $^{2}$, Marcus Schaub ${ }^{2}$, Pierre Vollenweider ${ }^{2}$, Rolf Siegwolf ${ }^{1,2}$ and Matthias Saurer ${ }^{1,2}$ 7

$8 \quad{ }^{1}$ Laboratory of Atmospheric Chemistry, Paul Scherrer Institute (PSI), Villigen 5232, Switzerland

$9 \quad{ }^{2}$ Research Unit Forest Dynamics, Swiss Federal Institute for Forest, Snow and Landscape Re-

10 search WSL, Birmensdorf 8903, Switzerland

$11{ }^{3}$ Institute of Terrestrial Ecosystems, ETH Zurich, Zurich 8092, Switzerland

$12 \quad{ }^{4}$ Department of Physics, University of Helsinki, Helsinki 00014, Finland

$13 \quad{ }^{5}$ School of GeoSciences, University of Edinburgh, EH9 3FF Edinburgh, UK

* Corresponding author: matthias.saurer@wsl.ch, tel. +41-44-7392198

Accepted in Tree Physiology

\section{Keywords:}

Stable isotopes, climate change, tree mortality, Pinus sylvestris, post-photosynthetic fractionation

This document is the accepted manuscript version of the following article:

Timofeeva, G., Treydte, K., Bugmann, H., Salmon, Y., Rigling, A., Schaub, M., ... Saurer, M. (2020). How does varying water supply affect oxygen isotope variations in needles and tree rings of scots pine? Tree Physiology, 40(10), 1366-1380. https://doi.org/10.1093/treephys/tpaa082 


\section{Abstract}

In many regions, drought is suspected to be a cause of Scots pine decline and mortality, but the underlying physiological mechanisms remain unclear. Because of their relationship to ecohydrological processes, $\delta^{18} \mathrm{O}$ values in tree rings are potentially useful for deciphering long-term physiological responses and tree adaptation to increasing drought. We therefore analysed both needle- and stem-level isotope fractionations in mature trees exposed to varying water supply. In a first experiment, we investigated seasonal $\delta^{18} \mathrm{O}$ variations in soil and needle water of Scots pine in a dry inner-Alpine valley in Switzerland, comparing drought-stressed trees with trees that were irrigated for more than 10 years. In a second experiment, we analysed $20^{\text {th }}$ century $\delta^{18} \mathrm{O}$ variations in tree rings of the same forest, including a group of trees that had recently died. We observed less ${ }^{18} \mathrm{O}$ enrichment in needle water of drought-stressed compared to irrigated trees. We applied different isotope fractionation models to explain these results, including the Péclet- and the two-pool correction which considers the ratio of unenriched xylem water in the needles to total needle water. Based on anatomical measurements, we found this ratio to be unchanged in drought-stressed needles, although they were shorter. The observed lower ${ }^{18} \mathrm{O}$ enrichment in needles of stressed trees was therefore likely caused by increased effective path length for water movement within the leaf lamina. In the tree-ring study, we observed lower $\delta^{18} \mathrm{O}$ values in tree rings of dead trees compared to survivors during several decades prior to their death. These lower values in declining trees are consistent with the lower needle water ${ }^{18} \mathrm{O}$ enrichment observed for drought-stressed compared to irrigated trees, suggesting this needle-level signal to be reflected in the tree-rings, although changes in rooting depth could also play a role. Our study demonstrates that long-term effects of drought are reflected in the tree-ring $\delta^{18} \mathrm{O}$ values, which helps providing a better understanding of past tree physiological changes of Scots pine. 


\section{Introduction}

Water is a key factor for plant growth and survival, and hence, understanding the variability in plant water uptake and transpiration is of paramount importance. This becomes even more pertinent in regions where plants experience acute or chronic drought that may lead to tree mortality (Allen et al. 2015; Allen et al. 2010; Anderegg et al. 2013; Choat et al. 2012). Understanding plant and particularly tree response to drought is a pressing issue in view of climate change, having triggered many studies (Breshears et al. 2013; McDowell et al. 2008). However, most experimental studies were performed with seedlings and saplings of various tree species (Cocozza et al. 2016; Duan et al. 2015; Galle et al. 2010; Pearson et al. 2013), and only rarely with mature trees (Aguadé et al. 2015; Galiano et al. 2010; Gaylord et al. 2015; Poyatos et al. 2013; Salmon et al. 2015). Therefore, drought manipulation studies in natural environments are crucial to further develop our understanding of the physiological responses of mature trees to drought, including associated isotope fractionations (Grossiord et al. 2018; Herzog et al. 2014; Rowland et al. 2015).

Stable oxygen isotope ratios (expressed as $\delta^{18} \mathrm{O}$ values) in plant organic matter have already been used to investigate ecophysiological and ecohydrological responses during drought (Moreno-Gutiérrez et al. 2012; Sargeant and Singer 2016). It is known that $\delta^{18} \mathrm{O}$ values of meteoric water are variable due to large-scale hydrological processes and temperature effects (Craig and Gordon 1965; Dansgaard 1964). These variations are reflected in soil water, with modification through mixing and evaporation. The soil water is taken up by plant roots without fractionation (Ehleringer and Dawson 1992), but in the leaves the isotope ratio is further changed owing to equilibrium and kinetic fractionation processes during transpiration (Dongmann et al. 1974; Farquhar et al. 2007) and carbohydrate production (Lehmann et al. 2017; Roden and Ehleringer 1999). Therefore, $\delta^{18} \mathrm{O}$ variations in plant organic matter such as tree rings are characterized by a complex, mixed isotope signal arising from the source water, the evaporative leaf water ${ }^{18} \mathrm{O}$ enrichment, and biochemical source-to-sink isotope fractionations (Gessler et al. 2014).

Although $\delta^{18} \mathrm{O}$ values in tree rings have often been used to reconstruct past environmental conditions (Edwards et al. 2008; Labuhn et al. 2016; Libby et al. 1976; Masson-Delmotte et al. 2005; Rinne et al. 2013; Treydte et al. 2006), these studies mainly relied on statistical relationships with climate variables and thus may not always adequately account for all 
processes (McCarroll and Loader 2004; Treydte et al. 2014). It would be important to apply mechanistic, process-based models for better understanding the factors controlling the isotope fractionation in foliage and tree rings related to various environmental conditions, including drought. The mechanistic Craig-Gordon model has often been applied to this end, mostly at the leaf-level (Craig and Gordon 1965; Farquhar and Lloyd 1993). It has been critically discussed that this model often overestimates leaf water ${ }^{18} \mathrm{O}$ enrichment and thus needs a correction for improved accuracy (Barbour 2007; Ogée et al. 2007). To date, there is no general correction approach suitable across different species. In many studies, the so-called Péclet correction was applied, requiring sometimes rather unrealistic adjustments of its parameters (Cernusak et al. 2016; Ferrio et al. 2012; Song et al. 2013). Therefore, it has been suggested that the so-called two-pool correction could be more adequate, particularly for conifers (Bögelein et al. 2017; Roden et al. 2015; Song et al. 2015) or a combination of the two-pool model and Péclet correction (HollowayPhillips et al. 2016). Additionally, current mechanistic models have been challenged by the limited understanding of post-photosynthetic isotope fractionation and the biochemical processes responsible for the incorporation of the cellulose oxygen isotopic signature into tree rings (Cheesman and Cernusak 2017; Gessler et al. 2009; Gessler et al. 2014; Ogée et al. 2009; Sternberg 2009; Waterhouse et al. 2002). During drought, various changes act in combination, such as temperature, source water composition, vapour pressure deficit, stomatal conductance and needle morphological properties. Therefore, it remains difficult to disentangle these factors and use $\delta^{18} \mathrm{O}$ in tree rings as a proxy for reconstructing long-term environmental changes or for better understanding causes of tree mortality.

In this study, we investigated a drought-stressed Scots pine population from one of the driest parts of the European Alps (Valais, Switzerland) that has been subjected to a longterm irrigation experiment since 2003. In a first experiment, we measured $\delta^{18} \mathrm{O}$ values in water extracted from different soil depths and needles of drought-stressed and irrigated trees sampled multiple times between 2013 and 2015. In a second experiment at the same site, we analyzed the $\delta^{18} \mathrm{O}$ values in tree-ring cellulose from Scots pine trees that had recently died and compared them with the signal from living trees over the period 19002014. Our first aim was to identify the factors controlling leaf-level isotope fractionation of Scots pine under drought and irrigation, considering evaporative leaf water enrichment, gas-exchange and needle morphological properties. Particularly, the basic Craig-Gordon 
model, Péclet and the two-pool correction were explored. Our second aim was to disentangle the effects of climate and tree physiology on long-term variations in $\delta^{18} \mathrm{O}$ by comparing measured tree-ring $\delta^{18} \mathrm{O}$ values with predicted ones using a fractionation model corrected with a similar approach as for needles. This should help to determine the driving factors of tree-ring oxygen isotope variability in drought-stressed Scots pine trees.

\section{Materials and methods}

Study site

The study was carried out in the Pfynwald forest ( $46^{\circ} 18^{\prime} \mathrm{N}, 7^{\circ} 36^{\prime} \mathrm{E}, 615 \mathrm{~m}$ a.s.1.) in Valais, Switzerland. The site is a natural Scots pine (Pinus sylvestris L.) forest located in one of the driest inner-Alpine valleys of the European Alps, where severe Scots pine decline and mortality have already been observed (Bigler et al. 2006; Rigling et al. 2013). The forest is characterized as uneven-aged Erico-Pinetum sylvestris with shallow soil and low water retention (Dobbertin et al. 2010). Because of the blockage of moist incoming oceanic air masses by the high surrounding mountain ranges, the climate in Central Valais is continental. For the 1981-2010 period, mean annual precipitation was $605 \mathrm{~mm}$, with $169 \mathrm{~mm}$ only during summer, while the mean annual temperature was $10.1{ }^{\circ} \mathrm{C}\left(19.1^{\circ} \mathrm{C}\right.$ for summer). In 2003, an irrigation experiment was initiated at this site (Dobbertin et al. 2010; Eilmann et al. 2010; Herzog et al. 2014), consisting of four drought-stressed and four irrigated plots of $1000 \mathrm{~m}^{2}$ each. The irrigation water was taken from a river channel near the experimental area, and irrigation took place every growing season between April and October. The irrigated trees received ca. twice the amount of total annual precipitation compared to the drought-stressed trees, i.e. approximately $1300 \mathrm{~mm}$.

\section{Sampling, sample preparation and measurements}

To measure seasonal $\delta^{18} \mathrm{O}$ variations in needle water, one tree per plot (i.e. four droughtstressed trees and four irrigated trees) was selected for repeated samplings between $\mathrm{Au}-$ gust 2013 and August 2015. Sampling was conducted every month from June to August and ca. every second month for the other periods. Several twigs were cut at a height of 10-12 $\mathrm{m}$ from the sun-exposed part of the crown using a pole pruner. Current-year needles were immediately separated from twigs, stored in air-tight glass vials with screw caps and placed in the dark in a cooling box with ice packs to minimize evaporative water loss. 
151 At the same sampling dates, soil samples from each plot (4 per treatment) were collected at two depths $(0-10$ and $10-20 \mathrm{~cm})$ and stored in air-tight glass vials to monitor seasonal $\delta^{18} \mathrm{O}$ variations of the soil water. Deeper sampling depths were generally not accessible due to the rocky soil. However, there was one soil profile down to $80 \mathrm{~cm}$ available, where soil samples were excavated on April 9th, 2014. Water samples from the channel (irrigation source) were collected at each sampling date as well. Increment cores from the four drought-stressed and four irrigated trees were sampled for stem water extraction in $\mathrm{Au}-$ gust and October 2014 (one $0.5 \mathrm{~cm}$ core per tree). Because xylem water was not systematically collected during the experiment in 2013-2015, twig phloem, twig xylem and stem xylem samples during August 2017 were taken to confirm the difference in source water between drought-stressed and irrigated trees.

Water from soil, needles and tree increment cores was obtained using a cryogenic vacuum extraction system (Saurer et al. 2016; West et al. 2006). In brief, glass vials with samples were placed in a water bath at $80{ }^{\circ} \mathrm{C}$. The evaporated water from samples was collected into U-shaped glass tubes that were cooled down with liquid nitrogen. Both glass vials with samples and tubes were connected to a vacuum system at ca. $4 \times 10^{-2}$ mbar. Subsequently, the extracted water samples were transferred into $2 \mathrm{ml}$ sealed glass vials. The $\delta^{18} \mathrm{O}$ values of these water samples were measured by injecting $0.6 \mu \mathrm{l}$ of the sample into a Thermal Conversion Elemental Analyzer (TC/EA; Thermo Finnigan, Bremen, Germany), where the water was pyrolysed in a glassy carbon reactor at $1450{ }^{\circ} \mathrm{C}$ to hydrogen $\left(\mathrm{H}_{2}\right)$ and carbon monoxide $(\mathrm{CO})$. These gases were carried in a helium stream to an isotope ratio mass spectrometer (IRMS) Delta plus XP (Thermo Finnigan, Bremen, Germany) for $\delta^{18} \mathrm{O}$ analysis. The results were reported in the standard $\delta$-notation as per mil

174 (\%) relative to the Vienna Standard Mean Ocean Water (VSMOW), with a precision of $175<0.2 \%$.

176 Twelve stem disks of standing dead trees (subsequently called "now-dead/dead trees") and increment cores from 32 trees ("now-living/living trees") were sampled within the non-irrigated (drought-stressed/ambient) area. Tree-ring widths (TRW) were measured at the tree-ring laboratory of the Swiss Federal Institute for Forest, Snow and Landscape Research WSL in Birmensdorf, Switzerland. The chronologies of the dead and living trees cover the period of 1900-2005 and 1900-2014, respectively. For details on sampling, sample preparation and TRW measurements see Timofeeva et al. (2017). For $\delta^{18} \mathrm{O}$ meas- 
183

184

185

186

187

188

189

190

191

192

193

194

195

196

197

198

199

200

201

202

203

204

205

206

207

208

209

210

211

212

213

214

urements, the tree-rings were separated according to calendar year and cellulose was extracted following Leavitt and Danzer (1993) and Boettger et al. (2007), with modifications according to Roden et al. (2009), and homogenized with an ultra-sonic device (Laumer et al. 2009). Aliquots were packed into silver capsules for isotope analyses, which were conducted using a pyrolysis method at $1420{ }^{\circ} \mathrm{C}$ in an elemental analyzer (PYRO-cube, Elementar, Hanau, Germany) connected to an Isotope Ratio Mass Spectrometer (IRMS, Delta Plus XP) via a Conflo III interface (Thermo Fischer Scientific, Bremen, Germany) (Weigt et al. 2015). In general, the measurement precision was better than $0.2 \%$.

\section{Needle gas exchange and anatomical measurements}

Leaf gas exchange, including net photosynthesis $\left(A_{\mathrm{N}}\right)$ and transpiration $(\mathrm{E})$ of five sunexposed twigs per tree ( 4 irrigated trees, 4 drought-stressed trees) were measured in June 2013 and May and June 2014. Measurements were performed using a portable photosynthesis system equipped with a 6400-22L leaf chamber (LI-COR 6400Xt; LI-COR, Lincoln, NE, USA). Conditions in the cuvette were kept constant during the measurements at $400 \mathrm{ppm}\left[\mathrm{CO}_{2}\right]$ and a photon flux density of $1,000 \mu \mathrm{mol} \mathrm{m} \mathrm{m}^{-2} \mathrm{~s}^{-1}$, while the temperature was adjusted close to ambient conditions. Initial leaf-gas exchange values were corrected a posteriori for the exact projected leaf area according to Fleck et al. (2016).

To measure the needle length of current-year needles, 10 trees at the drought-stressed and 12 trees at the irrigated plots were selected. Measurements were repeated every year during summer from 2013 to 2015 . For the anatomical assessments of needles, one branch from the sun crown of 5 trees per experimental plot was pole-pruned in February 2015. Needle samples from the last three needle generations were fixed in $2.5 \%$ glutaraldehyde buffered at $\mathrm{pH} 7.0$ with a $0.067 \mathrm{M}$ Soerensen phosphate buffer and stored at $4^{\circ} \mathrm{C}$ until processing (here, we only present data for the 2013 and 2014 needle generations). The size of tissues and histological composition were assessed using $70 \mu \mathrm{m}$ hand-microtomed cross-sections from the hydrated middle-part of needles. The cuttings were visually analysed with bright field microscopy using the 10x objective of a Leica microscope Leitz DMRB and imaged using the Lumenera INFINITY 2.1R camera and Lumenera Infinity Analyze (release 6.4) software (Lumenera Corp., Ottawa, Canada). The total area of needle cross-sections and that of each tissue (epidermis; hypodermis; resin ducts; mesophyll; 
215

216

217

218

219

220

221

222

223 224

225

226

227

228

229

230

231

232

233

234

235

236

237

238

239

240

241

242

243

244

245

246

247

endodermis; transfusion tissues; phloem; xylem) was determined by means of image analysis and the measurement tools in the Adobe Photoshop software (Cs5, version 12.0.0.0, Adobe Systems Inc., San Jose, CA, USA), using stitched micrographs. The histological composition was calculated by expressing each tissue in percentage area of the whole needle section.

\section{Oxygen isotope modelling}

As a first approximation, the needle water isotope ratio $\left(\delta^{18} \mathrm{O}_{\mathrm{N}}\right)$ in the steady-state can be calculated by the Craig \& Gordon (1965) equation modified by Dongmann et al. (1974):

$$
\delta^{18} \mathrm{O}_{\mathrm{N}}=\delta^{18} \mathrm{O}_{\mathrm{SW}}+\varepsilon^{+}+\varepsilon_{\mathrm{k}}+\left(\delta^{18} \mathrm{O}_{\mathrm{v}}-\delta^{18} \mathrm{O}_{\mathrm{SW}}-\varepsilon_{\mathrm{k}}\right) \cdot \mathrm{e}_{\mathrm{a}} / \mathrm{e}_{\mathrm{i}}
$$

where $\delta^{18} \mathrm{O}_{\mathrm{SW}}$ is the isotope value of the source water (xylem), $\varepsilon^{+}$is the equilibrium fractionation related to the phase change from liquid to vapour, $\varepsilon_{\mathrm{k}}$ is the kinetic fractionation related to the diffusion in air, $\delta^{18} \mathrm{O}_{\mathrm{v}}$ is the atmospheric water vapour isotope value, and $e_{a} / e_{i}$ is the ratio of leaf external (ambient) to internal water vapour pressures.

To exclusively characterize the isotope fractionation within the leaf without influences of the source water isotope variation, the leaf water enrichment term $\Delta^{18} \mathrm{O}_{\mathrm{N}}$ is often used, which is obtained after subtracting $\delta^{18} \mathrm{O}_{\mathrm{Sw}}$ from $\delta^{18} \mathrm{O}_{\mathrm{N}}$ :

$$
\Delta^{18} \mathrm{O}_{\mathrm{N}}=\varepsilon^{+}+\varepsilon_{\mathrm{k}}+\left(\delta^{18} \mathrm{O}_{\mathrm{v}}-\delta^{18} \mathrm{O}_{\mathrm{SW}}-\varepsilon_{\mathrm{k}}\right) \cdot \mathrm{e}_{\mathrm{a}} / \mathrm{e}_{\mathrm{i}}
$$

We refer to this equation as the CG-model ("Craig-Gordon-model”). The equilibrium fractionation $\left(\varepsilon^{+}\right)$depends on temperature and can be calculated according to Bottinga $\&$ Craig, (1968):

$$
\varepsilon^{+}(\%)=2.664-3.206 \cdot 10^{3} / \mathrm{T}+1.534 \cdot 10^{6} / \mathrm{T}^{2}
$$

The kinetic fractionation $\left(\varepsilon_{\mathrm{k}}\right)$ has an approximate value of $28 \%$ (Cernusak et al. 2016). The $e_{a} / e_{i}$ ratio can be simplified using relative air humidity $(\mathrm{RH})$ for the calculations, assuming that $\mathrm{RH}$ inside the leaf is $100 \%$ and that leaf and air temperatures are equal, although this may not always be the case, particularly for sun-exposed needles or leaves. 
248 Parts of equations 1 and 2, i.e. $\delta^{18} \mathrm{OV}_{\mathrm{v}}-\delta^{18} \mathrm{O}$ sw, can be replaced by $-\varepsilon^{+}$, assuming isotopic

249

250

251

252

253

254

255

256

257 258

259

260

261

262

263

264

265

266

267

268

269

270

271

272

273

274

275

276

277

278

279

280 equilibrium between soil (source) water and water vapour (Bögelein et al. 2017; Foerstel and Huetzen 1983).

Equations 1 and 2 were found to predict the variability of observed leaf water ${ }^{18} \mathrm{O}$ enrichment reasonably well (Cernusak et al. 2016; Farquhar and Lloyd 1993; Roden and Ehleringer 1999), but they often overestimate actual values. Therefore, a model correction based on the Péclet effect was proposed (Barbour 2007; Cernusak et al. 2016; Farquhar and Lloyd 1993). It can be characterized by the Péclet number $\wp$ and considers an isotopic gradient between xylem and evaporative sites, which is mainly driven by changes in transpiration (E) and the so-called effective path length (L):

$$
\wp=\mathrm{L} \cdot \mathrm{E} /(\mathrm{C} \cdot \mathrm{D})
$$

where $\mathrm{L}(\mathrm{m})$ describes the tortuous path that water travels from the leaf veins to the sites of evaporation, $\mathrm{E}$ is the transpiration rate $\left(\mathrm{mmol} \mathrm{m} \mathrm{m}^{-2} \mathrm{~s}^{-1}\right), \mathrm{C}$ is the molar density of water $\left(55.56 \times 10^{3} \mathrm{~mol} \mathrm{~m}^{-3}\right)$, and $\mathrm{D}$ is the diffusivity of $\mathrm{H}_{2}{ }^{18} \mathrm{O}$ in water, which depends on temperature (Cernusak et al. 2016; Cuntz et al. 2007). However, the effective path length (L) is not a directly measurable parameter and difficult to quantify. Mostly, as in our study, it is determined by an iterative procedure to minimize the square-root of the sum of all differences between measured and modelled values (Barbour et al. 2004).

Leaf ${ }^{18} \mathrm{O}$ enrichment after the Péclet correction is then given as

$$
\Delta^{18} \mathrm{O}_{\mathrm{N}}{ }^{*}=\Delta^{18} \mathrm{O}_{\mathrm{N}} \cdot\left(1-\mathrm{e}^{-\wp}\right) / \wp
$$

Furthermore, a two-pool model was suggested as a correction for the CG-model (Cernusak et al. 2016; Song et al. 2015; Yakir et al. 1990). It assumes that total needle water is a mixture of two discrete pools of water, i.e. unenriched water influenced mainly by xylem water (the central part of the needle consisting of endodermis, xylem, phloem, and transfusion tissues) and ${ }^{18} \mathrm{O}$ enriched water at the evaporative sites (mainly the mesophyll tissue), as follows:

$\Delta^{18} \mathrm{O}_{\mathrm{N}}{ }^{*}=\Delta^{18} \mathrm{O}_{\mathrm{N}} \cdot(1-\varphi)$ 
where $\varphi$ is the ratio of unenriched to total needle water (Cernusak et al. 2016; Song et al.

283

284

285

286

287

288

289

290

291

292

293

294

295

296

297

298

299

300

301

302

303

304

305

306

307

308

309

310

311

312

313

2015) and can be experimentally determined from needle-anatomical measurements (Roden et al. 2015). This ratio $\varphi$ can have a value between 0 (infinitely small xylem contribution) and 1 (xylem water fully dominates the ${ }^{18} \mathrm{O} /{ }^{16} \mathrm{O}$ ratio of needle water).

The two correction approaches can be combined, i.e. the Péclet correction is applied on the ${ }^{18} \mathrm{O}$ enriched part of the leaf water only (Holloway-Phillips et al. 2016):

$$
\Delta^{18} \mathrm{O}_{\mathrm{N}}{ }^{*}=(1-\varphi) \Delta^{18} \mathrm{O}_{\mathrm{N}} \cdot\left(1-\mathrm{e}^{-\wp}\right) / \wp
$$

A modified version of equation 1 can then be used to predict ${ }^{18} \mathrm{O}$ enrichment in tree rings:

$$
\delta^{18} \mathrm{O}_{\mathrm{TR}}=\delta^{18} \mathrm{O}_{\mathrm{SW}}+(1-x) \cdot \Delta^{18} \mathrm{O}_{\mathrm{N}}{ }^{*}+\varepsilon_{\mathrm{wc}}
$$

where $\delta^{18} \mathrm{O}_{\mathrm{TR}}$ is the predicted tree-ring isotope ratio, $\varepsilon_{\mathrm{wc}}$ is the biochemical exchange between the oxygen atoms of xylem water and those of the cellulose carbonyl groups, equaling 27 \%o (DeNiro and Epstein 1981; Sternberg et al. 1986), and $x$ is the proportion of oxygen atoms of carbonyl groups (e.g. of trioses) undergoing exchange with xylem (stem) water during cellulose formation $(x=0.42)$. The value of $x$ could vary as a function of the turnover of non-structural carbohydrates (Song et al. 2014) and environmental conditions (Cheesman and Cernusak 2017). This can also be expressed as a dampening $f$ of the leaf water signal as reflected in the tree-ring $f=1-x=0.58$ (Roden et al. 2000; Saurer et al. 1997; Treydte et al. 2014). As a surrogate for source water $\left(\delta^{18} \mathrm{O}_{\mathrm{sw}}\right)$ variations over the investigated period, we used the averages of summer months of $\delta^{18} \mathrm{O}$ in precipitation. The validity of this assumption was tested by comparison of measured soil $\delta^{18} \mathrm{O}$-values with monthly $\delta^{18} \mathrm{O}$ of precipitation (in Results). The needle water enrichment term $\Delta^{18} \mathrm{O}_{\mathrm{N}} *$ in Eq. 8 can be expressed with the simple leaf CG-model (Eq. 2), resulting in what we subsequently call the "tree-ring CG-model", or using the more advanced expression from Eq. 7 , resulting in the "full tree-ring model".

\section{Climate data}

For modeling of needle water ${ }^{18} \mathrm{O}$ enrichment, we used air temperature and relative humidity data from Pfynwald with 10 min resolution for the period of 2013-2015. These 
data were obtained from Sensirion SHT-21 sensors with a multiple-plate radiation shield ( $\pm 0.3{ }^{\circ} \mathrm{C}$ and $\pm 2 \% \mathrm{RH}$ accuracy). Monthly climate data for 1900 -2014 were obtained from the Sion meteorological station (MeteoSwiss archives). The Standardized Precipitation Evapotranspiration Index SPEI, a multiscalar drought index, was used for correlation analysis with tree-ring parameters (Timofeeva et al. 2017). Monthly $\delta^{18} \mathrm{O}$ data of precipitation were obtained from the Global Network of Isotopes in Precipitation (GNIP) and from the Federal Office of Water and Geology, Bern, Switzerland (FOWG). The GNIP data from the Grimsel station (46.57 N, 8.33 E, $1950 \mathrm{~m}$ a.s.1.) for the period 1972-2014 were used for tree-ring $\delta^{18} \mathrm{O}$ modeling. They were corrected for the elevational offset, using data from the Sion station for the period 1994-2014. To this end, we first calculated averages for each month for this period at both stations and used their differences for the correction. The raw data from the Sion station were not used for tree-ring modelling due to the short observation period.

\section{Data analysis}

We determined the response of $\delta^{18} \mathrm{O}$ variations to climate by calculating Pearson's correlation coefficients between the monthly mean series of each climate variable (air temperature, precipitation, relative humidity, drought index and VPD) and $\delta^{18} \mathrm{O}$ for individual months and seasons such as spring (March-May) and summer (June-August). We tested the significance of the correlation coefficients by applying two-tailed Student's t-tests. Temporal autocorrelation was taken into account by calculating the 'effective' sample size, which is based on sample size and the first-order autocorrelation for each time series and climate data:

where $N$ is sample size; $N^{\prime}$ is effective sample size; and $r_{1}$ and $r_{2}$ are the first-order sample autocorrelation of the first and second time series, respectively (Dawdy 1964). Two-tailed Student's t-tests were applied to test for significant differences between groups. Twofactorial ANOVA was carried out to test for treatment and needle generation differences in needle anatomical data, including a Tukey's HSD Post-Hoc test.

$$
N^{\prime}=N \cdot \frac{\left(1-r_{1} \cdot r_{2}\right)}{\left(1+r_{1} \cdot r_{2}\right)}
$$

$$
\text { in needle anatomical data, including a Tukey's HSD Post-Hoc test. }
$$




\section{$347 \quad$ Results}

348 Seasonal variations in $\delta^{18} O$ of needle and soil water

349 The $\delta^{18} \mathrm{O}$ values of needle water strongly fluctuated between sampling dates, showing 350 seasonal differences with values up to ca. $10 \%$ during spring and summer, and negative values during winter (Fig 1a). Soil water $\delta^{18} \mathrm{O}$ also featured a seasonal pattern at both measured soil depths, but with values always below zero (Fig. 1b,c). The $\delta^{18} \mathrm{O}$ values of the channel water (source of irrigation) did not show significant seasonal changes and were depleted compared to soil water during the growing season (Fig. 1b,c; p>0.05). This depletion resulted in soil water $\delta^{18} \mathrm{O}$ values of the irrigated plots to be clearly lower compared to the drought-stressed plots for both soil depths (significant for August 2013 and April 2014, $\mathrm{p}<0.05)$. Isotope values at soil depths from 0 to $10 \mathrm{~cm}$ were generally enriched in ${ }^{18} \mathrm{O}$ compared to those at soil depths from 10 to $20 \mathrm{~cm}$ during spring and summer (except for summer 2014). This strong enrichment of water near the soil surface was consistent with the results of the deep soil profile taken on 09.04.2014 (Fig. S1). This profile showed that below a depth of $20 \mathrm{~cm}$ there was less variation in the isotopic composition. Furthermore, stem water collected in August and October 2014 showed $\delta^{18} \mathrm{O}$ values close to soil water values from $20 \mathrm{~cm}$ depth rather than from top soil. Twig phloem, twig xylem and stem xylem samples taken after our experiment, while irrigation was still ongoing (August 2017), confirm the ${ }^{18} \mathrm{O}$ depletion of water taken up by irrigated trees compared to drought-stressed trees (Fig. S2). Considering all this information, the soil depth 10-20 $\mathrm{cm}$ was considered representative for the depth from where the source water was mainly taken up.

Needle water $\delta^{18} \mathrm{O}$ values did not show any significant differences between droughtstressed and irrigated trees $(\mathrm{p}>0.05)$. However, it is important to consider that soil water $\delta^{18} \mathrm{O}$ values of the irrigated plots were clearly lower compared to the drought-stressed plots due to lower $\delta^{18} \mathrm{O}$ values in the channel water used for irrigation. Accordingly, calculated needle water enrichment above source water $\left(\Delta^{18} \mathrm{O}\right)$ based on the difference between $\delta^{18} \mathrm{O}$ of needle water and water of soil depths $10-20 \mathrm{~cm}$ was higher for irrigated trees compared to the drought-stressed trees at almost all sampling points (Fig. 2). This divergence was most pronounced during spring and summer, although significant differences between drought-stressed and irrigated trees were only observed for August 2013 and April 2014 ( $p<0.05$ ), but not for the summer months of 2014 and 2015. 


\section{Gas exchange and needle properties}

Transpiration rate per leaf area was on average higher for the irrigated compared to the drought-stressed trees, except for the sampling in June 2013 (Table 1). However, differences between treatments were only marginally significant $(\mathrm{p}<0.1)$, whereas they were significant for the combined data of all tree in the treatment for both samplings in 2014 ( $p<0.01)$ and for the combined sampling dates over the period of 2013-2014 ( $<<0.05)$. These data were used to establish a linear relationship between E and VPD, which explained more than $60 \%$ of the variability in $\mathrm{E}$ and yielded a slope of $0.11 \mathrm{mmol} \mathrm{m}^{-2} \mathrm{sec}^{-1}$ $\mathrm{hPa}^{-1}$ for drought-stressed and $0.19 \mathrm{mmol} \mathrm{m}^{-2} \mathrm{sec}^{-1} \mathrm{hPa}^{-1}$ for irrigated trees. This relationship was subsequently used to estimate $\mathrm{E}$ on dates without gas-exchange measurements needed for leaf water modeling.

Needles of the drought-stressed trees were shorter (on average $34.67 \mathrm{~mm}$ ) compared to those of the irrigated trees (on average $44.31 \mathrm{~mm}$ ), with a high variability for both treatments (Table 2). Differences in needle length between drought-stressed and irrigated trees were significant both for the averaged and for all measured values for 2013 ( $\mathrm{p}<0.01$ ), $2014(\mathrm{p}<0.05)$ and over the period of 2013-2014 ( $<<0.001)$.

The cross-sectional area of the different needle tissues all showed a significant difference between the two needle generations (ANOVA, $\mathrm{p}<0.01$; Table 3 ). Treatment (i.e. droughtstressed vs. irrigated) was significant for resin, transfusion tissues, phloem and xylem, while no interaction between needle generation and treatment was found. Differences in total needle cross-section between the drought-stressed and irrigated trees were not significant. We estimated the proportion of tissue not subjected to evaporative ${ }^{18} \mathrm{O}$ enrichment $\varphi$ as the ratio of the sum of endodermis, xylem, phloem and transfusion tissues to total needle cross-section. This proportion amounted to $0.270 \pm 0.014$ for drought-stressed and $0.282 \pm 0.013$ for irrigated trees averaged over both needle generations. These values were used in the subsequent model calculations.

\section{Modeling needle water ${ }^{18} \mathrm{O}$ enrichment}

We found a highly significant correlation between measured and Craig-Gordon (CG)modelled needle water ${ }^{18} \mathrm{O}$ enrichment values using the basic equation (Eq. 2, Fig. 3). However, modeled values were only accurate for winter conditions, when ${ }^{18} \mathrm{O}$ enrichment was low, but they were strongly overestimated for both treatments (by up to 10\%o) during summer months (Fig. 3, Table 4). Accordingly, slopes of the linear regression strongly 
deviated from 1 (Fig. 3a, drought-stressed trees: slope $=0.44, R^{2}=0.66, p<0.01$; irrigated trees: slope $\left.=0.53, R^{2}=0.62, p<0.01\right)$. Furthermore, the basic CG model could not explain the observed difference in ${ }^{18} \mathrm{O}$ enrichment between treatments. Results obtained from the model incorporating the Péclet- and two-pool corrections (Eq. 7) reflected the variability of the data much better, as the linear regression slopes were closer to 1 (Fig. 3b, drought-stressed trees: slope $=0.88, R^{2}=0.67, p<0.01$; irrigated trees: slope $\left.=0.83, R^{2}=0.64, p<0.01\right)$. Furthermore, average growing season values calculated with this model were very close to measured ${ }^{18} \mathrm{O}$ enrichment for both treatments and the difference between treatments of about $3.5 \%$ was well reproduced (Table 4). These calculations were based on $\varphi$ derived from anatomical measurements and L optimized for minimum deviation from the data (Barbour et al. 2004). This resulted in high $\mathrm{L}$ of $0.32 \mathrm{~m}$ and $0.05 \mathrm{~m}$ for drought-stressed and irrigated groups, respectively. Even higher values of L of $0.7 \mathrm{~m}$ and $0.25 \mathrm{~m}$ would have resulted if neglecting the two-pool model (i.e. $\varphi=0$ ). Due to the high L, the Péclet effect $(\wp)$ was overall stronger for drought-stressed trees, despite the lower transpiration (Table 4), resulting in the lower ${ }^{18} \mathrm{O}$ enrichment observed compared to irrigated trees.

\section{Tree-ring $\delta^{18} O$ values and their relationship to climate}

The mean tree-ring $\delta^{18} \mathrm{O}$ chronologies calculated from the five living and five now-dead trees, respectively, were highly correlated for the common period (Fig. 4a, 1900-2004, $r$ $=0.76, p<0.001$ ), but also the mean inter-series correlations of the individual tree series for both groups where highly significant (Figs. S3 \& S4). The tree-ring $\delta^{18} \mathrm{O}$ chronologies of the living and the now-dead trees did not show any significant differences until the 1970s. After the 1970s, however, the records started to significantly deviate and remained lower for the now-dead trees until their death compared to the living trees (Fig. 4b, Student's t-test for differences between groups, 1900-1959: 0.130 0.118 (mean difference $\pm S D$ ), n.s.; 1960-2005: -0.786 $\pm 0.171, p<0.001)$. Correlation analysis between monthly climate variables and tree-ring $\delta^{18} \mathrm{O}$ chronologies indicated the spring (Mar-May) and summer (Jun-Aug) seasons as most important for isotope fixation in the tree rings, and we thus focused on the correlations for these periods. Tree-ring $\delta^{18} \mathrm{O}$ values of the living trees were positively and significantly correlated with spring temperatures and VPD (and negatively with $\mathrm{RH}$ ), as well as with summer temperatures, precipitation amount and SPEI (Fig. 5). For the now-dead trees, correlations were similar and in some cases also 
significant (spring VPD, summer precipitation amount and SPEI). Generally, trees that died later showed a weaker response in spring, but a stronger response in summer compared to living trees (Fig. 5).

\section{Modeling of $\delta^{18} \mathrm{O}$ in tree rings}

Simulations of tree-ring $\delta^{18} \mathrm{O}$ were performed for the time period where $\delta^{18} \mathrm{O}$ data of precipitation are available (starting in 1972). We verified the representativeness of the precipitation $\delta^{18} \mathrm{O}$ data as a surrogate for soil water isotopic composition by correlation analysis between measured seasonal soil water $\delta^{18} \mathrm{O}$ of the study site (available 2013-2015) and $\delta^{18} \mathrm{O}$ of precipitation of various months. We found a highly significant correlation between soil water values of 10-20 cm depth and 2-month precipitation averages (using the current and the preceding month; $\left.\mathrm{r}^{2}=0.70, \delta^{18} \mathrm{O}_{\mathrm{SW}}=0.8514 * \delta^{18} \mathrm{O}_{\text {precipitation }}+1.679\right)$. This relationship was used to estimate the isotopic composition of soil water available for the trees during the growing season over the extended period of 1972-2014. Other model parameters were used as determined above for the drought-stressed trees, including the relationship between $\mathrm{E}$ and VPD to estimate past variations in $\mathrm{E}$.

The correlation between measured and modeled tree-ring $\delta^{18} \mathrm{O}$ values was significant when using the basic tree-ring CG-model (Eq. 8) for dying and surviving trees (living trees: slope $=0.31, R^{2}=0.33, p<0.001$; dead trees: slope $=0.32, R^{2}=0.38, p<0.001$, although the slopes deviated strongly from 1 and the estimated values were too high by several per mil (Fig. 6). Applying the full model with the Péclet- and two-pool corrections in Eq. 8, simulated values were in better agreement with measurements regarding both the absolute level and the temporal variability (Fig. 6, living trees: slope $=0.38, R^{2}=$ $0.35, p<0.001$; dead trees: slope $\left.=0.39, R^{2}=0.41, p<0.001\right)$. Using a range of values for $\mathrm{L}$, based on the value obtained from the first experiment for drought-stressed trees ( $\mathrm{L}=0.32 \mathrm{~m} \pm 0.16 \mathrm{~m}$ ) shows the effect of this parameter on the tree-ring model results (Fig. 6). A higher $\mathrm{L}$ of $0.15 \mathrm{~m}$ for later dying trees compared to survivors would be consistent with the observed average tree-ring $\delta^{18} \mathrm{O}$ difference $(0.79 \%$ ) between the two groups. Furthermore, we attempted to explain remaining differences between modelled values for this range of $L$ and data by varying $x$ in Eq. 8. Accordingly, we found a range of $x=0.24$ to 0.37 for living trees, and a slightly higher range of $x=0.31$ to 0.43 for dead trees. 


\section{Discussion}

480

Comparison of measured and modelled needle water ${ }^{18} \mathrm{O}$ enrichment

482 In our first experiment on the seasonal variations in $\delta^{18} \mathrm{O}$ of different water pools, the estimated ${ }^{18} \mathrm{O}$ enrichment using the CG model was too high for both drought-stressed and irrigated trees compared to observations of $\Delta^{18} \mathrm{O}$, as often found in other studies (Cernusak et al. 2016), showing the need for a physiological correction. We also observed lower needle water ${ }^{18} \mathrm{O}$ enrichment for the drought-stressed compared to the irrigated trees that could not be explained by the basic CG-model, but by the full model considering the Péclet and two-pool corrections. The Péclet number $\wp$ is driven primarily by transpiration (E) and effective path length (L) and was shown to depend on water content and needle-anatomical traits (Liang et al. 2018). Under drought stress, transpiration often decreases due to lower stomatal conductance, as also observed at our site, which would reduce $\wp$ if $\mathrm{L}$ is unchanged (Eqs. 4, 5). Accordingly, needle water would be less diluted by re-filling with xylem water, and therefore higher needle $\Delta^{18} \mathrm{O}$ values could be expected under drought stress, whereas an unconstrained water supply and low VPD would result in lower needle $\Delta^{18} \mathrm{O}$ values. This was indeed observed in some studies (Roden and Ehleringer 1999; Yakir et al. 1990), but not in our case. However, $\wp$ depends also on the effective length of the water path within the leaf or needle, which can be affected by leaf/needle morpho-physiological changes under drought as well (Ferrio et al. 2012; Kahmen et al. 2008). Our results are therefore consistent assuming higher L for droughtstressed needles.

501 For deciduous plants, L can be estimated reasonably well (Kahmen et al. 2009), but for conifers, estimating $\mathrm{L}$ is often challenging, mostly due to the varying structure of a needle, its low conductance, and generally low transpiration. Very high estimates of more than one meter for L have previously been reported for various coniferous species, including pine (Song et al. 2013). Such values seem unrealistically high compared to the actual needle length, but could be related to the tortuosity of the water path and reduced hydrau-

507 lic conductivity due to the xeromorphic structure of the needle. In gymnosperms, hydrau508 lic connections between the xylem and the mesophyll are weak and the endodermis pro509 vides a hydraulic separation between the vascular strand and the rest of the needle (Zwieniecki et al. 2007). 
511 By considering the two-pool model as in the full model, the Péclet correction is applied

512 to the ${ }^{18} \mathrm{O}$-enriched portion of needle water only and $\mathrm{L}$ is thus reduced (Holloway-Phillips

513 et al. 2016). The two-pool model was originally proposed more than two decades ago

514 (Gat and Bowser 1991; Yakir et al. 1990), but it has only recently been revived with the

515 expectation that it may be superior to the Péclet model (Bögelein et al. 2017; Song et al.

516 2015). The advantage of the two-pool model is that its parameters are more easily acces-

517 sible to direct observation. The model was found to explain well e.g. the different ${ }^{18} \mathrm{O}$

518 enrichment in old compared to young needles (Roden et al. 2015). When the proportion

519 of the mesophyll tissue surrounding the needle xylem is relatively small (high $\varphi$ value),

520 the needle water signal will be strongly dominated by the unenriched xylem water, result-

521 ing in low $\Delta^{18} \mathrm{O}$ according to the two-pool model. In our study, needle length of the

522 drought-stressed trees was significantly lower than those of the irrigated ones. However,

523 based on anatomical measurements, the calculated proportions of unenriched to enriched

524 tissue did not change significantly (Table 3). This shows that needle shrinkage, i.e. the

525 lower total cross-sectional area of the drought-stressed needles, was a result of smaller

526 dimensions of all needle tissues. Our results and particularly the difference between irri-

527 gated and drought-stressed trees can therefore not be explained by the two-pool model

528 alone, but its consideration is still important for proper application of the Péclet model.

529 One implicit assumption in the leaf models is the isotopic equilibrium between soil water 530 and water vapour. This may not always be true, particularly under dry conditions, owing 531 to soil evaporation effects (Bögelein et al. 2017; Ueta et al. 2013). There could also be a 532 difference in relative humidity or $\delta^{18} \mathrm{O}_{\mathrm{v}}$ between drought-stressed and irrigated plots. We 533 think, however, that such influence of added water to the soil is rapidly diluted in the air 534 at 10-12 meters canopy height. Furthermore, it is crucial to use representative source wa535 ter $\delta^{18} \mathrm{O}$ values for modeling, particularly considering root distribution and isotopic gra536 dients at different depths (Saurer et al. 2016; Treydte et al. 2014). Uncertainties regarding 537 the soil depth from which trees take up water tend to be large. We used $\delta^{18} \mathrm{O}$ values from 538 the lower soil depth $(10-20 \mathrm{~cm})$, rather than values from the top layer, which were ${ }^{18} \mathrm{O}$ 539 enriched due to evaporation from the soil surface. However, even when using the topsoil 540 water values as the source, calculated needle water ${ }^{18} \mathrm{O}$ enrichment of the drought-stressed 541 trees was still lower than the one of the irrigated trees. In addition, the $\delta^{18} \mathrm{O}$ soil water 542 values down to $80 \mathrm{~cm}$ determined from soil excavation did not show strong deviations 
543

544

545

546

547

548

549

550

551

552

553

554

555

556

557

558

559

560

561

562

563

564

565

566

567

568

569

570

571

572

573

574

575

compared to those from $20 \mathrm{~cm}$, suggesting that the source water values we used are likely to be appropriate.

Overall, the irrigation experiment enabled us to disentangle the effects of drought on needle-level oxygen isotope fractionation in mature trees, and we captured the important seasonal driving factors of needle water isotopic fractionation at our study site. This is an important prerequisite for understanding the tree-ring $\delta^{18} \mathrm{O}$ values.

\section{Tree-ring $\delta^{18} \mathrm{O}$ variations in living and now-dead trees}

The tree-ring $\delta^{18} \mathrm{O}$ values of the individual living and now-dead trees as well as the means of the two groups featured very strong common variability (Figs. 4a, S3, S4). Our correlation analysis suggested that mainly spring mean temperature and VPD were responsible for the common $\delta^{18} \mathrm{O}$ variations of both groups, consistent with earlier studies (Giuggiola et al. 2016; Treydte et al. 2014; Treydte et al. 2007). This can be explained by the effect of high temperatures on the isotope ratios of precipitation and source water (Dansgaard 1964), and by the higher foliar water ${ }^{18} \mathrm{O}$ enrichment under dry conditions (Roden and Ehleringer 1999), in general agreement with the factors known to influence oxygen isotope fractionations (Eq. 8). It is also consistent with the occurrence of frequent droughts in the studied region (Bigler et al. 2006; Rigling et al. 2013). However, dead trees were more depleted in $\delta^{18} \mathrm{O}$ compared to the surviving trees after the 1970s (Fig. 4b). This indicates that climate alone cannot explain the isotope variability, but some site-specific soil or plant physiological differences must exist between the tree groups. The results from our seasonal water samples suggested that ${ }^{18} \mathrm{O}$ enrichment in drought-stressed trees was generally lower compared to the irrigated trees, owing to changes in needle morphology. This fits well to the lower tree-ring isotope values of the now-dead (i.e., more stressed) trees compared to the survivors. The lower needle water ${ }^{18} \mathrm{O}$ enrichment was related to higher effective path length $\mathrm{L}$ in drought-stressed trees and it could therefore be possible that such a signal is recorded in the tree-rings. This hypothesis will be further discussed in the modelling section below.

However, a direct mechanistic link between needle-level and stem-level signals is difficult to establish. Lower tree-ring $\delta^{18} \mathrm{O}$ values in declining trees could also be related to seasonal differences in the use of carbohydrates (Sarris et al. 2013). Drought-stressed trees react more sensitively to favorable spring and early summer environmental conditions and therefore rely more on isotopically depleted source water from winter and 
576

577

578

579

580

581

582

583

584

585

586

587

588

589

590

591

592

593

594

595

596

597

598

599

600

601

602

603

604

605

606

607

608

spring. Tree rings may therefore reflect the isotopic signature of carbohydrates produced during the earlier part of the growing season rather than during very dry conditions in summer (Pflug et al. 2015; Sarris et al. 2013). Furthermore, lower tree-ring $\delta^{18} \mathrm{O}$ values in stressed trees may be related to different rooting patterns and associated changes in depth of the water source compared to more healthy trees (Brinkmann et al. 2019; Volkmann et al. 2016). However, this is unlikely at our site, as the lower values would imply deeper roots of the later dying trees. This would be unexpected for already weakened trees.

Long-term differences in gas-exchange between dying and surviving trees are indicated by a tree-ring study based on carbon isotopes at the same site (Timofeeva et al. 2017). The authors found that individuals with the most isohydric strategy were most prone to suffer as a result of long-term reduced carbon uptake (Timofeeva et al. 2017). As atmospheric moisture demand has been increasing during recent decades due to higher temperatures and more frequent drought (Rebetez and Dobbertin 2004), Scots pine trees tended to close their stomata and strongly reduced transpiration - potentially already for many decades at our study site. This does, however, not need to be the case on the verge of death, as dying Scots pines in Spain transpired even more than healthy individuals (Salmon et al. 2015). More insights into causes of the tree-ring isotope variations could be expected by the use of the isotope fractionation model.

\section{Tree-ring isotope model}

We applied isotope fractionation models only over the period where isotope data of precipitation were available (1972-2014). Nevertheless, the availability of such a long precipitation $\delta^{18} \mathrm{O}$ record is precious and restricted to only a few sites globally. Modeling of $\delta^{18} \mathrm{O}$ variations in tree-ring cellulose is more challenging (Roden et al. 2000; Saurer et al. 2012; Treydte et al. 2014) than modeling of changes in leaf/needle water $\delta^{18} \mathrm{O}$ values (Barbour 2007; Cernusak et al. 2016). Besides the problem of the unknown source water isotope variability, including uncertainty about the seasonal distribution of precipitation in the soil, the transfer of the isotope signal from leaf water to organic compounds in leaves such as sucrose and later cellulose is complex and involves isotope fractionation at various steps (Gessler et al. 2014; Treydte et al. 2014). Fractionations may occur because of the use of stored carbohydrates or during phloem loading and transport, but the 
609

610

611

612

613

614

615

616

617

618

619

620

621

622

623

624

625

626

627

628

629

630

631

632

633

634

635

636

637

638

639

640

strongest modifications are observed during cellulose formation due to exchange of carbonyl groups with xylem water, thus diluting the leaf isotope signal (Lehmann et al. 2017; Sternberg et al. 1986). Therefore, previous studies faced challenges in extracting a leaf physiological signal from tree-ring cellulose/wood $\delta^{18} \mathrm{O}$ variations (Ogée et al. 2009; Treydte et al. 2014).

In our study, tree-ring cellulose $\delta^{18} \mathrm{O}$ values estimated with the basic CG model were too high. However, applying the full model with an optimized Péclet path length (L) correction for each group of trees (Eq. 8) strongly improved the agreement between data and model. The $\mathrm{L}$ values obtained were higher for the later dying trees $(\mathrm{L}=0.48 \mathrm{~m})$ compared to surviving trees $(\mathrm{L}=0.16 \mathrm{~m})$, consistent with lower transpiration rates for the more stressed trees. These values are in similar range as those obtained from modeling the seasonal needle data $(\mathrm{L}=0.32 \mathrm{~m}$ vs. $0.05 \mathrm{~m})$. However, other model parameters could also differ between the groups of trees, notably the proportion $\mathrm{x}$ of isotope exchange with xylem water during cellulose formation (Cheesman and Cernusak 2017; Song et al. 2014). In a study with eucalyptus trees in Australia, $\mathrm{x}$ was estimated to range from 0.21 to 0.68 and increase with increasing site aridity (Cheesman and Cernusak 2017). Based on a functional link between $\mathrm{x}$ and the turnover of non-structural carbohydrates (Song et al. 2014), this would suggest high cycling of triose phosphates in stem tissues in dry environments, although in Song et al. (2014) the change of $\mathrm{x}$ with precipitation amount was not significant. In our study, we find relatively low values, which are, however, not far from the generally assumed $\mathrm{x}=0.42$ for heterotrophic cellulose synthesis from sucrose. Values are slightly higher for later dying, i.e. more stressed trees (0.31 to 0.43$)$ compared to living trees $(0.24$ to 0.37$)$, which would be consistent with a higher turnover of non-structural carbohydrates in stem tissues. This makes sense in a carbon-limited situation as a small sucrose pool is turned over quickly during cellulose synthesis with less opportunity for hexose phosphates to cycle through triose.

\section{Conclusions}

A combination of observed data and model simulations enabled us to derive valuable information on past tree physiological changes at our site. Interestingly, lower $\delta^{18} \mathrm{O}$ values were also observed for declining Norway spruce (Picea abies L. Karst.) at two sites in Norway (Hentschel et al. 2014). In this study, the authors concluded that such behavior 
641 may be due to changes in anatomical and physiological traits of trees under drought con642 ditions, which could be examined to infer the risk of future tree decline. Therefore, such 643 changes and related isotope traces under drought could be common for conifers, and $\delta^{18} \mathrm{O}$ may be helpful for estimating the 'health status' of trees, particularly in combination with $\delta^{13} \mathrm{C}$ (Gessler et al. 2018; Scheidegger et al. 2000). Our results are among the first demon-

646

647

648

649

650

651

652

653

654

655

656

657

658

659

660

661

662

663

664

665

666

667

668

669

670

671

672

673

674

675

676 strating needle-level changes in ${ }^{18} \mathrm{O}$ enrichment of trees exposed to long-term drought could be reflected in the $\delta^{18} \mathrm{O}$-variations of tree rings. This method can potentially be applied either for retrospectively analyzing past tree-physiological changes, or even to predict decline and/or mortality of vulnerable trees.

\section{Acknowledgments}

We gratefully acknowledge the technical assistance by Magdalena Nötzli, Anne Verstege, Loic Schneider, Dieter Trummer, Walter Godli and Crest Simeon with wood sampling, preparation and measurements at ETH and WSL and by Theresia Lindner with the anatomical assessments at WSL. We also thank the technical coordinators of the Pfynwald Irrigation Experiment, Peter Bleuler and Christian Hug, for their support and Lola Schmid for stable isotope measurements. Furthermore, we thank Katja Rinne, Jan Blees, Rosemarie Barbara Weigt, Marco Lehmann, Lucia Galiano, Quim Canelles, Linda Feichtinger, as well as Konrad Egger and his team from Forstrevier Leuk for their assistance.

\section{Funding}

This study was financially supported by the Swiss State Secretariat for Education, Research and Innovation (SBFI) under COST Action FP1106 'STREeSS' (grant no. SBFC12.0093), SNF (No. 200020_182092 to M. Saurer; 200021_175888 to K. Treydte) and by NERC (RA0929 to M. Mencuccini) and the Academy of Finland (1284701 to T. Vesala).

\section{References}

Aguadé, D., R. Poyatos, T. Rosas and J. Martínez-Vilalta. 2015. Comparative drought responses of Quercus ilex L. and Pinus sylvestris L. In a montane forest undergoing a vegetation shift. Forests. 6:2505-2529.

Allen, C.D., D.D. Breshears and N.G. McDowell. 2015. On underestimation of global vulnerability to tree mortality and forest die-off from hotter drought in the Anthropocene. Ecosphere. 6:1-55.

Allen, C.D., A.K. Macalady, H. Chenchouni, D. Bachelet, N. McDowell, M. Vennetier, T. Kitzberger, A. Rigling, D.D. Breshears and E.T. Hogg. 2010. A global overview of drought and heat- 
induced tree mortality reveals emerging climate change risks for forests. Forest Ecology and Management. 259:660-684.

Anderegg, W.R.L., J.M. Kane and L.D.L. Anderegg. 2013. Consequences of widespread tree mortality triggered by drought and temperature stress. Nature Clim. Change. 3:30-36.

Barbour, M.M. 2007. Stable oxygen isotope composition of plant tissue: a review. Functional Plant Biology. 34:83-94.

Barbour, M.M., J.S. Roden, G.D. Farquhar and J.R. Ehleringer. 2004. Expressing leaf water and cellulose oxygen isotope ratios as enrichment above source water reveals evidence of a Peclet effect. Oecologia. 138:426-435.

Bigler, C., O.U. Bräker, H. Bugmann, M. Dobbertin and A. Rigling. 2006. Drought as an inciting mortality factor in Scots pine stands of the Valais, Switzerland. Ecosystems. 9:330-343.

Boettger, T., M. Haupt, K. Knöller, S.M. Weise, J.S. Waterhouse, K.T. Rinne, N.J. Loader, E. Sonninen, H. Jungner, V. Masson-Delmotte, M. Stievenard, M.-T. Guillemin, M. Pierre, A. Pazdur, M. Leuenberger, M. Filot, M. Saurer, C.E. Reynolds, G. Helle and G.H. Schleser. 2007. Wood cellulose preparation methods and mass spectrometric analyses of $\delta^{13} \mathrm{C}$, $\delta^{18} \mathrm{O}$, and nonexchangeable $\delta^{2} \mathrm{H}$ values in cellulose, sugar, and starch: An interlaboratory comparison. Analytical Chemistry. 79:4603-4612.

Bögelein, R., F.M. Thomas and A. Kahmen. 2017. Leaf water ${ }^{18} \mathrm{O}$ and ${ }^{2} \mathrm{H}$ enrichment along vertical canopy profiles in a broadleaved and a conifer forest tree. Plant, Cell \& Environment:doi: 10.1111/pce.12895.

Bottinga, Y. and H. Craig. 1968. Oxygen isotope fractionation between $\mathrm{CO}_{2}$ and water, and the isotopic composition of marine atmospheric $\mathrm{CO}_{2}$. Earth and Planetary Science Letters. 5:285-295.

Breshears, D.D., H.D. Adams, D. Eamus, N.G. McDowell, D.J. Law, R.E. Will, A.P. Williams and C.B. Zou. 2013. The critical amplifying role of increasing atmospheric moisture demand on tree mortality and associated regional die-off. Frontiers in Plant Science. 4

Brinkmann, N., W. Eugster, N. Buchmann and A. Kahmen. 2019. Species-specific differences in water uptake depth of mature temperate trees vary with water availability in the soil. Plant Biology. 21:71-81.

Cernusak, L.A., M.M. Barbour, S.K. Arndt, A.W. Cheesman, N.B. English, T.S. Feild, B.R. Helliker, M.M. Holloway-Phillips, J.A.M. Holtum, A. Kahmen, F.A. McInerney, N.C. Munksgaard, K.A. Simonin, X. Song, H. Stuart-Williams, J.B. West and G.D. Farquhar. 2016. Stable isotopes in leaf water of terrestrial plants. Plant, Cell \& Environment. 39:1087-1102.

Cheesman, A.W. and L.A. Cernusak. 2017. Infidelity in the outback: climate signal recorded in $\Delta^{18} \mathrm{O}$ of leaf but not branch cellulose of eucalypts across an Australian aridity gradient. Tree Physiology. 37:554-564.

Choat, B., S. Jansen, T.J. Brodribb, H. Cochard, S. Delzon, R. Bhaskar, S.J. Bucci, T.S. Feild, S.M. Gleason, U.G. Hacke, A.L. Jacobsen, F. Lens, H. Maherali, J. Martinez-Vilalta, S. Mayr, M. Mencuccini, P.J. Mitchell, A. Nardini, J. Pittermann, R.B. Pratt, J.S. Sperry, M. Westoby, I.J. Wright and A.E. Zanne. 2012. Global convergence in the vulnerability of forests to drought. Nature. 491:752-755.

Cocozza, C., M. de Miguel, E. Pšidová, L.u. Ditmarová, S. Marino, L. Maiuro, A. Alvino, T. Czajkowski, A. Bolte and R. Tognetti. 2016. Variation in Ecophysiological Traits and Drought Tolerance of Beech (Fagus sylvatica L.) Seedlings from Different Populations. Frontiers in Plant Science. 7:886.

Craig, H. and L.I. Gordon. 1965. Deuterium and Oxygen 18 Variations in the Ocean and the Marine Atmosphere. Consiglio nazionale delle richerche, Laboratorio de geologia nucleare.

Cuntz, M., J. Ogée, G.D. Farquhar, P. Peylin and L.A. Cernusak. 2007. Modelling advection and diffusion of water isotopologues in leaves. Plant, Cell \& Environment. 30:892-909.

Dansgaard, W. 1964. Stable isotopes in precipitation. Tellus. 16:436-468. 
Dawdy, D.R. 1964. Statistical and probability analysis of hydrologic data, part III: Analysis of variance, covariance and time series, in Handbook of Applied Hydrology, edited by Ven Te Chow. 868-890 p.

DeNiro, M.J. and S. Epstein. 1981. Isotopic composition of cellulose from aquatic organisms. Geochimica et Cosmochimica Acta. 45:1885-1894.

Dobbertin, M., B. Eilmann, P. Bleuler, A. Giuggiola, E.G. Pannatier, W. Landolt, P. Schleppi and A. Rigling. 2010. Effect of irrigation on needle morphology, shoot and stem growth in a drought-exposed Pinus sylvestris forest. Tree Physiology. 30:346-360.

Dongmann, G., H.W. Nürnberg, H. Förstel and K. Wagener. 1974. On the enrichment of $\mathrm{H}_{2}{ }^{18} \mathrm{O}$ in the leaves of transpiring plants. Radiation and Environmental Biophysics. 11:41-52.

Duan, H., A.P. O'Grady, R.A. Duursma, B. Choat, G. Huang, R.A. Smith, Y. Jiang and D.T. Tissue. 2015. Drought responses of two gymnosperm species with contrasting stomatal regulation strategies under elevated $\left[\mathrm{CO}_{2}\right]$ and temperature. Tree Physiology. 35:756770.

Edwards, T.W.D., S.J. Birks, B.H. Luckman and G.M. MacDonald. 2008. Climatic and hydrologic variability during the past millennium in the eastern Rocky Mountains and northern Great Plains of western Canada. Quaternary Research. 70:188-197.

Ehleringer, J.R. and T.E. Dawson. 1992. Water uptake by plants: perspectives from stable isotope composition. Plant, Cell \& Environment. 15:1073-1082.

Eilmann, B., N. Buchmann, R. Siegwolf, M. Saurer, P. Cherubini and A. Rigling. 2010. Fast response of Scots pine to improved water availability reflected in tree-ring width and $\delta^{13} \mathrm{C}$. Plant, Cell \& Environment. 33:1351-1360.

Farquhar, G.D., L.A. Cernusak and B. Barnes. 2007. Heavy water fractionation during transpiration. Plant Physiol. 143:11-8.

Farquhar, G.D. and J. Lloyd. 1993. Carbon and Oxygen Isotope Effects in the Exchange of Carbon Dioxide between Terrestrial Plants and the Atmosphere. In Stable Isotopes and Plant Carbon-water Relations. Academic Press, San Diego, pp 47-70.

Ferrio, J.P., A. Pou, I. Florez-Sarasa, A. Gessler, N. Kodama, J. Flexas and M. Ribas-Carbó. 2012. The Péclet effect on leaf water enrichment correlates with leaf hydraulic conductance and mesophyll conductance for $\mathrm{CO}_{2}$. Plant, Cell \& Environment. 35:611-625.

Fleck, S., S. Raspe, M. Cater, P. Schleppi, L. Ukonmaanaho, M. Greve, C. Hertel, W. Weis, S. Rumpf, A. Thimonier, F. Chianucci and P. Beckschäfer. 2016. Part XVII: Leaf Area Measurements. In: UNECE ICP Forests Programme Co-ordinating Centre (ed.): Manual on methods and criteria for harmonized sampling, assessment, monitoring and analysis of the effects of air pollution on forests. Thünen Institute of Forest Ecosystems, Eberswalde, Germany. 44 p. p.

Foerstel, H. and H. Huetzen. $1983 .{ }^{18} \mathrm{O} /{ }^{16} \mathrm{O}$ ratio of water in a local ecosystem as a basis of climate record. IAEA, International Atomic Energy Agency (IAEA).

Galiano, L., J. Martínez-Vilalta and F. Lloret. 2010. Drought-Induced Multifactor Decline of Scots Pine in the Pyrenees and Potential Vegetation Change by the Expansion of Co-occurring Oak Species. Ecosystems. 13:978-991.

Galle, A., J. Esper, U. Feller, M. Ribas-Carbo and P. Fonti. 2010. Responses of wood anatomy and carbon isotope composition of Quercus pubescens saplings subjected to two consecutive years of summer drought. Annals of Forest Science. 67:809-809.

Gat, J.R. and C. Bowser. 1991. The heavy isotope enrichment of water in coupled evaporative systems. In Stable Isotope Geochemistry: A Tribute to Samuel Epstein Eds. H.P. Taylor, Jr., J.R. O'Neil and I.R. Kaplan.

Gaylord, M.L., T.E. Kolb and N.G. McDowell. 2015. Mechanisms of piñon pine mortality after severe drought: a retrospective study of mature trees. Tree Physiology. 35:806-816. 
Gessler, A., E. Brandes, N. Buchmann, G. Helle, H. Rennenberg and R.L. Barnard. 2009. Tracing carbon and oxygen isotope signals from newly assimilated sugars in the leaves to the tree-ring archive. Plant, Cell \& Environment. 32:780-795.

Gessler, A., M. Cailleret, J. Joseph, L. Schonbeck, M. Schaub, M. Lehmann, K. Treydte, A. Rigling, G. Timofeeva and M. Saurer. 2018. Drought induced tree mortality - a tree-ring isotope based conceptual model to assess mechanisms and predispositions. New Phytologist. 219:485-490.

Gessler, A., J.P. Ferrio, R. Hommel, K. Treydte, R.A. Werner and R.K. Monson. 2014. Stable isotopes in tree rings: towards a mechanistic understanding of isotope fractionation and mixing processes from the leaves to the wood. Tree Physiology. 34:796-818.

Giuggiola, A., J. Ogée, A. Rigling, A. Gessler, H. Bugmann and K. Treydte. 2016. Improvement of water and light availability after thinning at a xeric site: which matters more? A dual isotope approach. New Phytologist. 210:108-121.

Grossiord, C., S. Sevanto, J.M. Limousin, P. Meir, M. Mencuccini, R.E. Pangle, W.T. Pockman, Y. Salmon, R. Zweifel and N.G. McDowell. 2018. Manipulative experiments demonstrate how long-term soil moisture changes alter controls of plant water use. Environmental and Experimental Botany. 152:19-27.

Hentschel, R., S. Rosner, Z.E. Kayler, K. Andreassen, I. Børja, S. Solberg, O.E. Tveito, E. Priesack and A. Gessler. 2014. Norway spruce physiological and anatomical predisposition to dieback. Forest Ecology and Management. 322:27-36.

Herzog, C., J. Steffen, E. Graf Pannatier, I. Hajdas and I. Brunner. 2014. Nine Years of Irrigation Cause Vegetation and Fine Root Shifts in a Water-Limited Pine Forest. PLoS ONE. 9:e96321.

Holloway-Phillips, M., L.A. Cernusak, M. Barbour, X. Song, A. Cheesman, N. Munksgaard, H. Stuart-Williams and G.D. Farquhar. 2016. Leaf vein fraction influences the Péclet effect and ${ }^{18} \mathrm{O}$ enrichment in leaf water. Plant Cell and Environment. 39:2414-2427.

Kahmen, A., K. Simonin, K. Tu, G.R. Goldsmith and T.E. Dawson. 2009. The influence of species and growing conditions on the 18-O enrichment of leaf water and its impact on 'effective path length'. New Phytologist. 184:619-630.

Kahmen, A., K. Simonin, K.P. Tu, A. Merchant, A. Callister, R. Siegwolf, T.E. Dawson and S.K. Arndt. 2008. Effects of environmental parameters, leaf physiological properties and leaf water relations on leaf water $\delta^{18} \mathrm{O}$ enrichment in different Eucalyptus species. Plant, Cell \& Environment. 31:738-751.

Labuhn, I., V. Daux, O. Girardclos, M. Stievenard, M. Pierre and V. Masson-Delmotte. 2016. French summer droughts since $1326 \mathrm{CE}$ : a reconstruction based on tree ring cellulose $\delta^{18} \mathrm{O}$. Climate of the Past. 12:1101-1117.

Laumer, W., L. Andreu, G. Helle, G.H. Schleser, T. Wieloch and H. Wissel. 2009. A novel approach for the homogenization of cellulose to use micro-amounts for stable isotope analyses. Rapid Commun Mass Spectrom. 23:1934-40.

Leavitt, S.W. and S.R. Danzer. 1993. Method for batch processing small wood samples to holocellulose for stable-carbon isotope analysis. Analytical Chemistry. 65:87-89.

Lehmann, M.M., B. Gamarra, A. Kahmen, R.T.W. Siegwolf and M. Saurer. 2017. Oxygen isotope fractionations across individual leaf carbohydrates in grass and tree species. Plant, Cell \& Environment. 40:1658-1670.

Liang, J., J.S. Wright, X.W. Cui, L. Sternberg, W.X. Gan and G.H. Lin. 2018. Leaf anatomical traits determine the 0-18 enrichment of leaf water in coastal halophytes. Plant Cell and Environment. 41:2744-2757.

Libby, L.M., L.J. Pandolfi, P.H. Payton, J. Marshall, B. Becker and V. Giertz-Sienbenlist. 1976. Isotopic tree thermometers. Nature. 261:284-288.

Masson-Delmotte, V., G. Raffalli-Delerce, P.A. Danis, P. Yiou, M. Stievenard, F. Guibal, O. Mestre, V. Bernard, H. Goosse, G. Hoffmann and J. Jouzel. 2005. Changes in European 
precipitation seasonality and in drought frequencies revealed by a four-century-long tree-ring isotopic record from Brittany, western France. Climate Dynamics. 24:57-69.

McCarroll, D. and N.J. Loader. 2004. Stable isotopes in tree rings. Quaternary Science Reviews. 23:771-801.

McDowell, N.G., W.T. Pockman, C.D. Allen, D.D. Breshears, N. Cobb, T. Kolb, J. Plaut, J. Sperry, A. West, D.G. Williams and E.A. Yepez. 2008. Mechanisms of plant survival and mortality during drought: why do some plants survive while others succumb to drought? New Phytologist. 178:719-739.

Moreno-Gutiérrez, C., T.E. Dawson, E. Nicolás and J.I. Querejeta. 2012. Isotopes reveal contrasting water use strategies among coexisting plant species in a Mediterranean ecosystem. New Phytologist. 196:489-496.

Ogée, J., M.M. Barbour, L. Wingate, D. Bert, A. Bosc, M. Stievenard, C. Lambrot, M. Pierre, T. Bariac, D. Loustau and R.C. Dewar. 2009. A single-substrate model to interpret intraannual stable isotope signals in tree-ring cellulose. Plant, Cell \& Environment. 32:10711090.

Ogée, J., M. Cuntz, P. Peylin and T. Bariac. 2007. Non-steady-state, non-uniform transpiration rate and leaf anatomy effects on the progressive stable isotope enrichment of leaf water along monocot leaves. Plant, Cell \& Environment. 30:367-387.

Pearson, M., M. Saarinen, L. Nummelin, J. Heiskanen, M. Roitto, T. Sarjala and J. Laine. 2013. Tolerance of peat-grown Scots pine seedlings to waterlogging and drought: Morphological, physiological, and metabolic responses to stress. Forest Ecology and Management. 307:43-53.

Pflug, E.E., R. Siegwolf, N. Buchmann, M. Dobbertin, T.M. Kuster, M.S. Günthardt-Goerg and M. Arend. 2015. Growth cessation uncouples isotopic signals in leaves and tree rings of drought-exposed oak trees. Tree Physiology. 35:1095-1105.

Poyatos, R., D. Aguadé, L. Galiano, M. Mencuccini and J. Martínez-Vilalta. 2013. Drought-induced defoliation and long periods of near-zero gas exchange play a key role in accentuating metabolic decline of Scots pine. New Phytologist. 200:388-401.

Rebetez, M. and M. Dobbertin. 2004. Climate change may already threaten Scots pine stands in the Swiss Alps. Theoretical and Applied Climatology. 79:1-9.

Rigling, A., C. Bigler, B. Eilmann, E. Feldmeyer-Christe, U. Gimmi, C. Ginzler, U. Graf, P. Mayer, G. Vacchiano, P. Weber, T. Wohlgemuth, R. Zweifel and M. Dobbertin. 2013. Driving factors of a vegetation shift from Scots pine to pubescent oak in dry Alpine forests. Global Change Biology. 19:229-240.

Rinne, K.T., N.J. Loader, V.R. Switsur and J.S. Waterhouse. 2013. 400-year May-August precipitation reconstruction for Southern England using oxygen isotopes in tree rings. Quaternary Science Reviews. 60:13-25.

Roden, J., A. Kahmen, N. Buchmann and R. Siegwolf. 2015. The enigma of effective path length for ${ }^{18} \mathrm{O}$ enrichment in leaf water of conifers. Plant, Cell \& Environment. 38:2551-2565.

Roden, J.S. and J.R. Ehleringer. 1999. Observations of Hydrogen and Oxygen Isotopes in Leaf Water Confirm the Craig-Gordon Model under Wide-Ranging Environmental Conditions. Plant Physiology. 120:1165-1174.

Roden, J.S., J.A. Johnstone and T.E. Dawson. 2009. Intra-annual variation in the stable oxygen and carbon isotope ratios of cellulose in tree rings of coast redwood (Sequoia sempervirens). The Holocene. 19:189-197.

Roden, J.S., G. Lin and J.R. Ehleringer. 2000. A mechanistic model for interpretation of hydrogen and oxygen isotope ratios in tree-ring cellulose. Geochimica et Cosmochimica Acta. 64:21-35.

Rowland, L., A.C.L. da Costa, D.R. Galbraith, R.S. Oliveira, O.J. Binks, A.A.R. Oliveira, A.M. Pullen, C.E. Doughty, D.B. Metcalfe, S.S. Vasconcelos, L.V. Ferreira, Y. Malhi, J. Grace, M. 
Mencuccini and P. Meir. 2015. Death from drought in tropical forests is triggered by hydraulics not carbon starvation. Nature. 528:119-122.

Salmon, Y., J.M. Torres-Ruiz, R. Poyatos, J. Martinez-Vilalta, P. Meir, H. Cochard and M. Mencuccini. 2015. Balancing the risks of hydraulic failure and carbon starvation: a twig scale analysis in declining Scots pine. Plant, Cell \& Environment. 38:2575-2588.

Sargeant, C.I. and M.B. Singer. 2016. Sub-annual variability in historical water source use by Mediterranean riparian trees. Ecohydrology. 9:1328-1345.

Sarris, D., R. Siegwolf and C. Körner. 2013. Inter- and intra-annual stable carbon and oxygen isotope signals in response to drought in Mediterranean pines. Agricultural and Forest Meteorology. 168:59-68.

Saurer, M., K. Aellen and R. Siegwolf. 1997. Correlating $\delta^{13} C$ and $\delta^{18} \mathrm{O}$ in cellulose of trees. Plant Cell and Environment. 20:1543-1550.

Saurer, M., A.V. Kirdyanov, A.S. Prokushkin, K.T. Rinne and R.T.W. Siegwolf. 2016. The impact of an inverse climate-isotope relationship in soil water on the oxygen-isotope composition of Larix gmelinii in Siberia. New Phytologist. 209:955-964.

Saurer, M., A. Kress, M. Leuenberger, K.T. Rinne, K.S. Treydte and R.T.W. Siegwolf. 2012. Influence of atmospheric circulation patterns on the oxygen isotope ratio of tree rings in the Alpine region. Journal of Geophysical Research: Atmospheres. 117:2156-2202.

Scheidegger, Y., M. Saurer, M. Bahn and R. Siegwolf. 2000. Linking stable oxygen and carbon isotopes with stomatal conductance and photosynthetic capacity: a conceptual model. Oecologia. 125:350-357.

Song, X., G.D. Farquhar, A. Gessler and M.M. Barbour. 2014. Turnover time of the non-structural carbohydrate pool influences $\delta^{18} \mathrm{O}$ of leaf cellulose. Plant Cell and Environment. 37:2500-2507.

Song, X., K.E. Loucos, K.A. Simonin, G.D. Farquhar and M.M. Barbour. 2015. Measurements of transpiration isotopologues and leaf water to assess enrichment models in cotton. New Phytologist. 206:637-646.

Song, X.I.N., M.M. Barbour, G.D. Farquhar, D.R. Vann and B.R. Helliker. 2013. Transpiration rate relates to within- and across-species variations in effective path length in a leaf water model of oxygen isotope enrichment. Plant, Cell \& Environment. 36:1338-1351.

Sternberg, L. 2009. Oxygen stable isotope ratios of tree-ring cellulose: the next phase of understanding. New Phytologist. 181:553-62.

Sternberg, L., M.J. Deniro and R.A. Savidge. 1986. Oxygen Isotope Exchange between Metabolites and Water during Biochemical Reactions Leading to Cellulose Synthesis. Plant Physiology. 82:423-427.

Timofeeva, G., K. Treydte, H. Bugmann, A. Rigling, M. Schaub, R. Siegwolf and M. Saurer. 2017. Long-term effects of drought on tree-ring growth and carbon isotope variability in Scots pine in a dry environment. Tree Physiol:1-14.

Treydte, K., S. Boda, E. Graf Pannatier, P. Fonti, D. Frank, B. Ullrich, M. Saurer, R. Siegwolf, G. Battipaglia, W. Werner and A. Gessler. 2014. Seasonal transfer of oxygen isotopes from precipitation and soil to the tree ring: source water versus needle water enrichment. New Phytologist. 202:772-783.

Treydte, K., D. Frank, J. Esper, L. Andreu, Z. Bednarz, F. Berninger, T. Boettger, C.M. D'Alessandro, N. Etien, M. Filot, M. Grabner, M.T. Guillemin, E. Gutierrez, M. Haupt, G. Helle, E. Hilasvuori, H. Jungner, M. Kalela-Brundin, M. Krapiec, M. Leuenberger, N.J. Loader, V. Masson-Delmotte, A. Pazdur, S. Pawelczyk, M. Pierre, O. Planells, R. Pukiene, C.E. Reynolds-Henne, K.T. Rinne, A. Saracino, M. Saurer, E. Sonninen, M. Stievenard, V.R. Switsur, M. Szczepanek, E. Szychowska-Krapiec, L. Todaro, J.S. Waterhouse, M. Weigl and G.H. Schleser. 2007. Signal strength and climate calibration of a European tree-ring isotope network. Geophysical Research Letters. 34:L24302. 
Treydte, K.S., G.H. Schleser, G. Helle, D.C. Frank, M. Winiger, G.H. Haug and J. Esper. 2006. The twentieth century was the wettest period in northern Pakistan over the past millennium. Nature. 440:1179-1182.

Ueta, A., A. Sugimoto, Y. lijima, H. Yabuki, T.C. Maximov, T.A. Velivetskaya and A.V. Ignatiev. 2013. Factors controlling diurnal variation in the isotopic composition of atmospheric water vapour observed in the taiga, eastern Siberia. Hydrological Processes. 27:22952305.

Volkmann, T.H.M., K. Haberer, A. Gessler and M. Weiler. 2016. High-resolution isotope measurements resolve rapid ecohydrological dynamics at the soil-plant interface. New Phytologist. 210:839-849.

Waterhouse, J.S., V.R. Switsur, A.C. Barker, A.H.C. Carter and I. Robertson. 2002. Oxygen and hydrogen isotope ratios in tree rings: how well do models predict observed values? Earth and Planetary Science Letters. 201:421-430.

Weigt, R.B., S. Bräunlich, L. Zimmermann, M. Saurer, T.E.E. Grams, H.-P. Dietrich, R.T.W. Siegwolf and P.S. Nikolova. 2015. Comparison of $\delta^{18} \mathrm{O}$ and $\delta^{13} \mathrm{C}$ values between tree-ring whole wood and cellulose in five species growing under two different site conditions. Rapid Communications in Mass Spectrometry. 29:2233-2244.

West, A.G., S.J. Patrickson and J.R. Ehleringer. 2006. Water extraction times for plant and soil materials used in stable isotope analysis. Rapid Commun Mass Spectrom. 20:1317-21.

Yakir, D., M.J. DeNiro and J.R. Gat. 1990. Natural deuterium and oxygen-18 enrichment in leaf water of cotton plants grown under wet and dry conditions: evidence for water compartmentation and its dynamics. Plant, Cell \& Environment. 13:49-56.

Zwieniecki, M.A., T.J. Brodribb and N.M. Holbrook. 2007. Hydraulic design of leaves: insights from rehydration kinetics. Plant Cell and Environment. 30:910-921. 
Table 1. Transpiration rates for the period of 2013-2014. Numbers are mean values of four trees \pm standard deviation. NA - not available (only one tree measured).

\begin{tabular}{|c|c|c|}
\hline \multirow{2}{*}{ Date } & \multicolumn{2}{|c|}{ Transpiration rate $\left(\mathrm{mmol} \mathrm{m}^{-2} \mathrm{~s}^{-1}\right)$} \\
\cline { 2 - 3 } & Drought-stressed & Irrigated \\
\hline 18.06 .2013 & $0.35 \pm 0.08$ & $0.36 \pm 0.17$ \\
06.05 .2014 & $0.22 \pm 0.07$ & $1.01 \pm \mathrm{NA}$ \\
03.06 .2014 & $0.12 \pm 0.05$ & $0.21 \pm 0.05$ \\
$2013-2014$ & $0.24 \pm 0.12$ & $0.43 \pm 0.34$ \\
\hline
\end{tabular}


Table 2. Needle length data determined during summer 2013 and 2014. Numbers are mean values ( \pm standard deviation) of 10 drought-stressed and 12 irrigated trees.

\begin{tabular}{|c|c|c|}
\hline \multirow{2}{*}{ Date } & \multicolumn{2}{|c|}{$\begin{array}{c}\text { Needle length } \\
(\mathrm{mm})\end{array}$} \\
\cline { 2 - 3 } & Drought-stressed & Irrigated \\
\hline 2013 & $38.77 \pm 7.61$ & $48.24 \pm 7.27$ \\
2014 & $30.57 \pm 8.57$ & $40.38 \pm 8.45$ \\
$2013-2014$ & $34.67 \pm 8.94$ & $44.31 \pm 8.69$ \\
\hline
\end{tabular}


Table 3. Average cross-sectional areas of different tissues ( \pm standard deviation) for both treatments and two needle generations as well as the proportion of isotopically non-enriched tissue. Non-enriched is defined as the sum of endodermis, xylem, phloem and transfusion tissues.

\begin{tabular}{|c|c|c|c|c|c|c|c|c|c|c|}
\hline $\begin{array}{l}\text { Treat- } \\
\text { ment }\end{array}$ & $\begin{array}{c}\text { needle } \\
\text { gener- } \\
\text { ation }\end{array}$ & $\begin{array}{l}\text { needle } \\
\left(\mathrm{mm}^{2}\right)\end{array}$ & $\begin{array}{c}\text { Epider- } \\
\text { mis }+ \\
\text { hypoder- } \\
\text { mis } \\
\left(\mathrm{mm}^{2}\right)\end{array}$ & $\begin{array}{l}\text { resin } \\
\text { ducts } \\
\left(\mathrm{mm}^{2}\right)\end{array}$ & $\begin{array}{l}\text { meso- } \\
\text { phyll } \\
\left(\mathrm{mm}^{2}\right)\end{array}$ & $\begin{array}{l}\text { Endo- } \\
\text { dermis } \\
\left(\mathrm{mm}^{2}\right)\end{array}$ & $\begin{array}{l}\text { Transfu- } \\
\text { sion } \\
\text { tissues } \\
\left(\mathrm{mm}^{2}\right)\end{array}$ & $\begin{array}{c}\text { Phloem } \\
\left(\mathrm{mm}^{2}\right)\end{array}$ & $\begin{array}{c}\text { Xylem } \\
\left(\mathrm{mm}^{2}\right)\end{array}$ & $\begin{array}{l}=\text { non-enri- } \\
\text { ched/total }\end{array}$ \\
\hline $\begin{array}{l}\text { Drought } \\
\text {-stressed }\end{array}$ & 2013 & $\begin{array}{r}0.868 \\
\pm 0.137\end{array}$ & $\begin{array}{r}0.128 \\
\pm 0.016\end{array}$ & $\begin{array}{r}0.091 \\
\pm 0.017\end{array}$ & $\begin{array}{r}0.415 \\
\pm 0.067\end{array}$ & $\begin{array}{r}0.040 \\
\pm 0.007\end{array}$ & $\begin{array}{r}0.166 \\
\pm 0.036\end{array}$ & $\begin{array}{r}0.020 \\
\pm 0.004\end{array}$ & $\begin{array}{r}0.008 \\
\pm 0.002\end{array}$ & $\begin{array}{r}0.269 \\
\pm 0.015\end{array}$ \\
\hline Irrigated & 2013 & $\begin{array}{r}0.900 \\
\pm 0.187\end{array}$ & $\begin{array}{r}0.132 \\
\pm 0.019\end{array}$ & $\begin{array}{r}0.097 \\
\pm 0.026\end{array}$ & $\begin{array}{r}0.417 \\
\pm 0.095\end{array}$ & $\begin{array}{r}0.040 \\
\pm 0.006\end{array}$ & $\begin{array}{r}0.180 \\
\pm 0.042\end{array}$ & $\begin{array}{r}0.024 \\
\pm 0.007\end{array}$ & $\begin{array}{r}0.012 \\
\pm 0.004\end{array}$ & $\begin{array}{r}0.283 \\
\pm 0.013\end{array}$ \\
\hline $\begin{array}{l}\text { Drought } \\
\text {-stressed }\end{array}$ & 2014 & $\begin{array}{r}0.694 \\
\pm 0.131\end{array}$ & $\begin{array}{r}0.110 \\
\pm 0.017\end{array}$ & $\begin{array}{r}0.074 \\
\pm 0.015\end{array}$ & $\begin{array}{r}0.322 \\
\pm 0.065\end{array}$ & $\begin{array}{r}0.031 \\
\pm 0.005\end{array}$ & $\begin{array}{r}0.138 \\
\pm 0.031\end{array}$ & $\begin{array}{r}0.013 \\
\pm 0.003\end{array}$ & $\begin{array}{r}0.006 \\
\pm 0.002\end{array}$ & $\begin{array}{r}0.271 \\
\pm 0.014\end{array}$ \\
\hline Irrigated & 2014 & $\begin{array}{r}0.810 \\
\pm 0.211\end{array}$ & $\begin{array}{r}0.121 \\
\pm 0.023\end{array}$ & $\begin{array}{r}0.088 \\
\pm 0.026\end{array}$ & $\begin{array}{r}0.373 \\
\pm 0.106\end{array}$ & $\begin{array}{r}0.036 \\
\pm 0.007\end{array}$ & $\begin{array}{r}0.166 \\
\pm 0.049\end{array}$ & $\begin{array}{r}0.016 \\
\pm 0.005\end{array}$ & $\begin{array}{r}0.010 \\
\pm 0.003\end{array}$ & $\begin{array}{r}0.281 \\
\pm 0.012\end{array}$ \\
\hline
\end{tabular}


Table 4. List of parameters and leaf water model results calculated as average of all sampling days during the growing seasons (omitting Oct-Feb data). The equilibrium fractionation $\varepsilon+$ is calculated according to Eq. 3, the diffusivity D according to Cuntz et al. (2007), the path length $\mathrm{L}$ obtained through optimization (see text for details), the Péclet number $\wp$ calculated with Eq. 4, the proportion of isotopically non-enriched tissue $\varphi$ determined from anatomical measurements. $\Delta^{18} \mathrm{O}_{\mathrm{N}}$ is the measured difference between $\delta^{18} \mathrm{O}_{\mathrm{N}}$ and $\delta^{18} \mathrm{O}_{\text {soil }} 20 \mathrm{~cm}, \Delta^{18} \mathrm{O}_{\mathrm{CG}}$ calculated according to Eq. 2 and $\Delta{ }^{18} \mathrm{O}_{\text {full model }}$ according to Eq. 7.

\begin{tabular}{|l|rr|}
\hline Parameter & drought-stressed & irrigated \\
\hline$\varepsilon^{+}(\%)$ & 8.94 & 8.82 \\
$\varepsilon_{\mathrm{k}}(\%)$ & 28 & 28 \\
$\mathrm{D}\left(\mathrm{m}^{2} \mathrm{~s}^{-1}\right)$ & $2.53 \mathrm{e}-09$ & $2.62 \mathrm{e}-09$ \\
$\mathrm{~L}(\mathrm{~m})$ & 0.32 & 0.05 \\
$\mathrm{E}\left(\mathrm{mmol} \mathrm{m}^{-2} \mathrm{~s}^{-1}\right)$ & 0.28 & 0.55 \\
$\mathrm{EL}\left(\mathrm{mmol} \mathrm{m}^{-1} \mathrm{~s}^{-1}\right)$ & 0.09 & 0.03 \\
$\wp$ & 0.63 & 0.19 \\
$\varphi$ & 0.27 & 0.28 \\
$\delta^{18} \mathrm{O}_{\text {soil }} 20 \mathrm{~cm}(\%)$ & -6.84 & -9.43 \\
$\delta^{18} \mathrm{O}_{\mathrm{N}}(\%)$ & 5.99 & 6.90 \\
$\Delta^{18} \mathrm{O}_{\mathrm{N}}(\%)$ & 12.83 & 16.33 \\
$\Delta^{18} \mathrm{O}_{\mathrm{GG}}(\%)$ & 23.31 & 24.76 \\
$\Delta^{18} \mathrm{O}_{\text {full model }}(\%)$ & 12.62 & 16.15 \\
\hline
\end{tabular}




\section{Figure captions}

Fig. 1. Seasonal variations in $\delta^{18} \mathrm{O}$ of needle water (a), soil water at $0-10 \mathrm{~cm}$ (b) and at 10-20 cm (c) shown for drought-stressed and ambient plots. Isotope values of channel water used for irrigation are displayed as stars $(b, c)$.

Fig. 2. Seasonal changes in needle water ${ }^{18} \mathrm{O}$ enrichment $\left(\Delta^{18} \mathrm{O}\right)$ calculated as difference between needle water $\delta^{18} \mathrm{O}$ and soil water at $10-20 \mathrm{~cm}$.

Fig. 3. Relationship between measured and predicted needle water ${ }^{18} \mathrm{O}$ enrichment using the basic Craig-Gordon model (Eq. 2, a) and the full model with the combined Pécletand two-pool correction (Eq. 7, b). Regression lines and equations are also indicated. The dashed lines show $95 \%$ confidence intervals.

Fig. 4. Tree-ring $\delta^{18} \mathrm{O}$ chronologies of living and now-dead trees (a) and their differences (b). The dashed lines indicate the mean of the differences between dead and living for 1900-1959 and 1960-2005, respectively. Note: the chronology of the dead trees covers the period 1900-2005.

Fig. 5. Pearson's correlation coefficients between $\delta^{18} \mathrm{O}$ chronologies and climate variables ( $\mathrm{T}$ - mean temperature, $\mathrm{P}$ - precipitation amount, SPEI - standardized precipitationevapotranspiration index ( $3 \mathrm{~m}=3$ months, $6 \mathrm{~m}=6$ months $)$, $\mathrm{RH}-$ relative humidity, VPD - vapour pressure deficit) for the period of 1960-2003 for spring (March-May; a) and summer (June to August; b). White bars refer to living trees and black bars to dead trees. Significant correlations are marked by $*(\mathrm{P}<0.05)$ and $* *(\mathrm{P}<0.01)$.

Fig. 6. Time series of observed (living/now-dead) and predicted tree-ring cellulose $\delta^{18} \mathrm{O}$ values using the basic and the full CG-model with the Péclet and two-pool corrections (Eq. 8). The effect of varying $\mathrm{L}$ in the full model is also shown. 


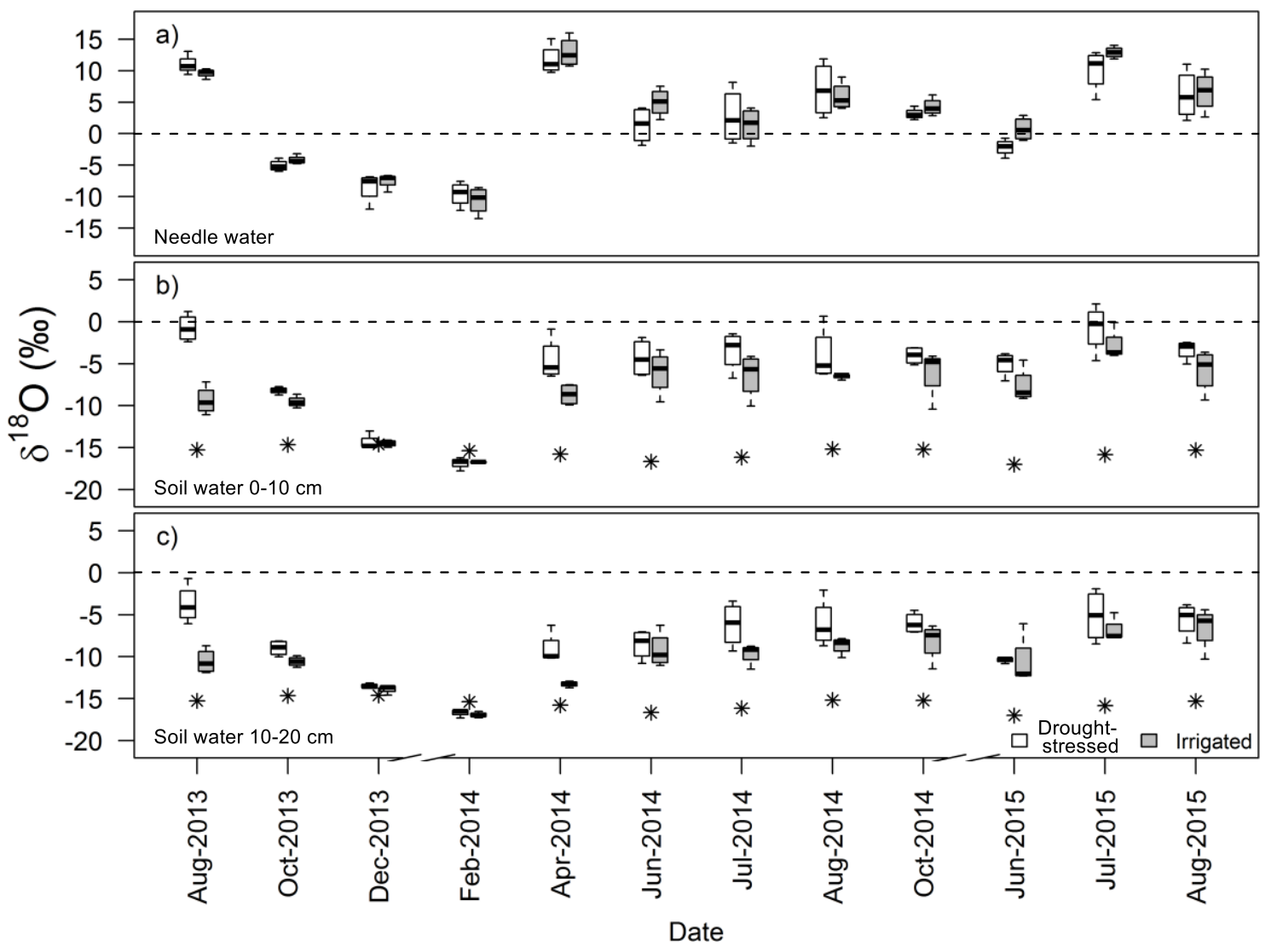

Figure 1. 


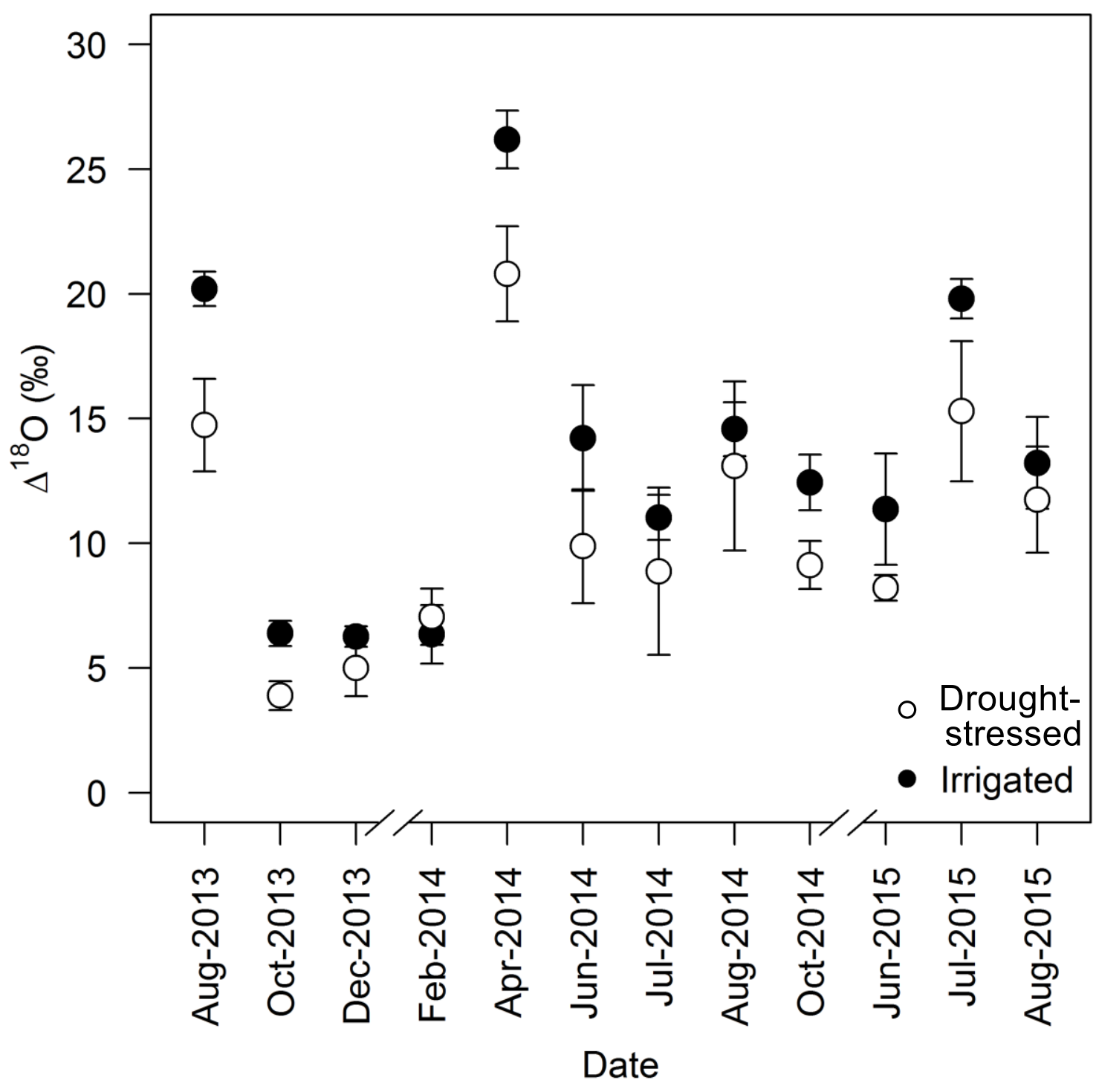

Figure 2. 

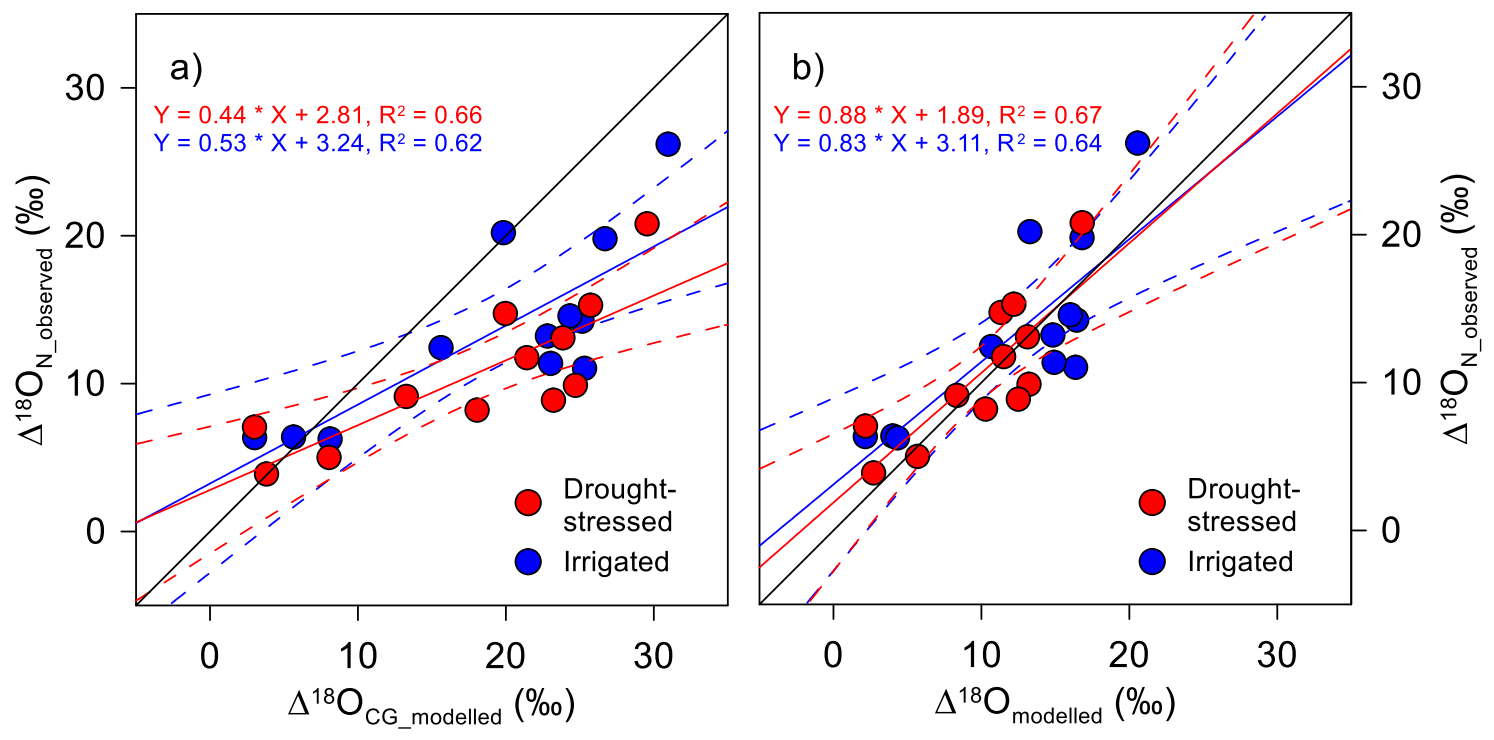

Figure 3. 


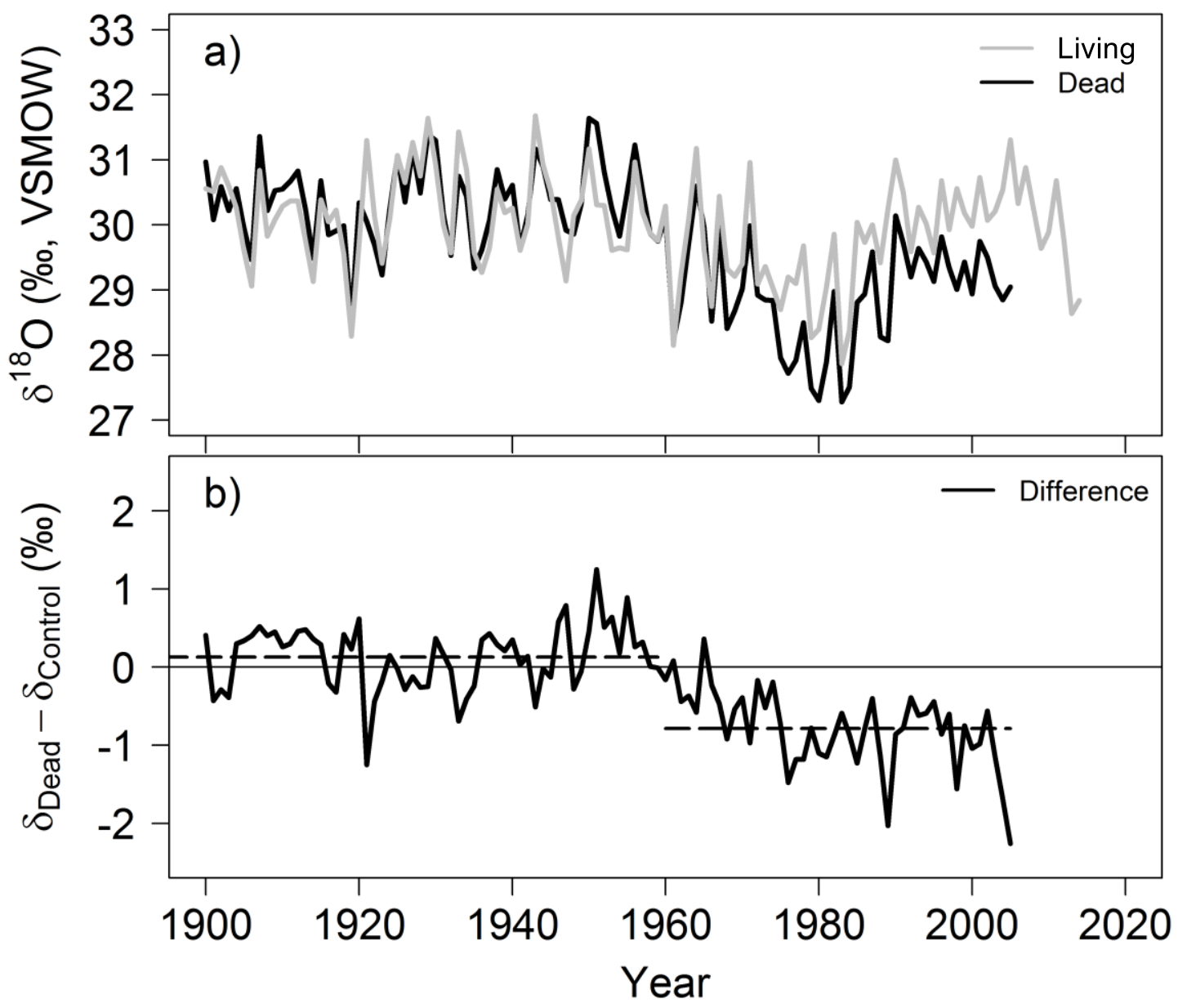

Figure 4. 


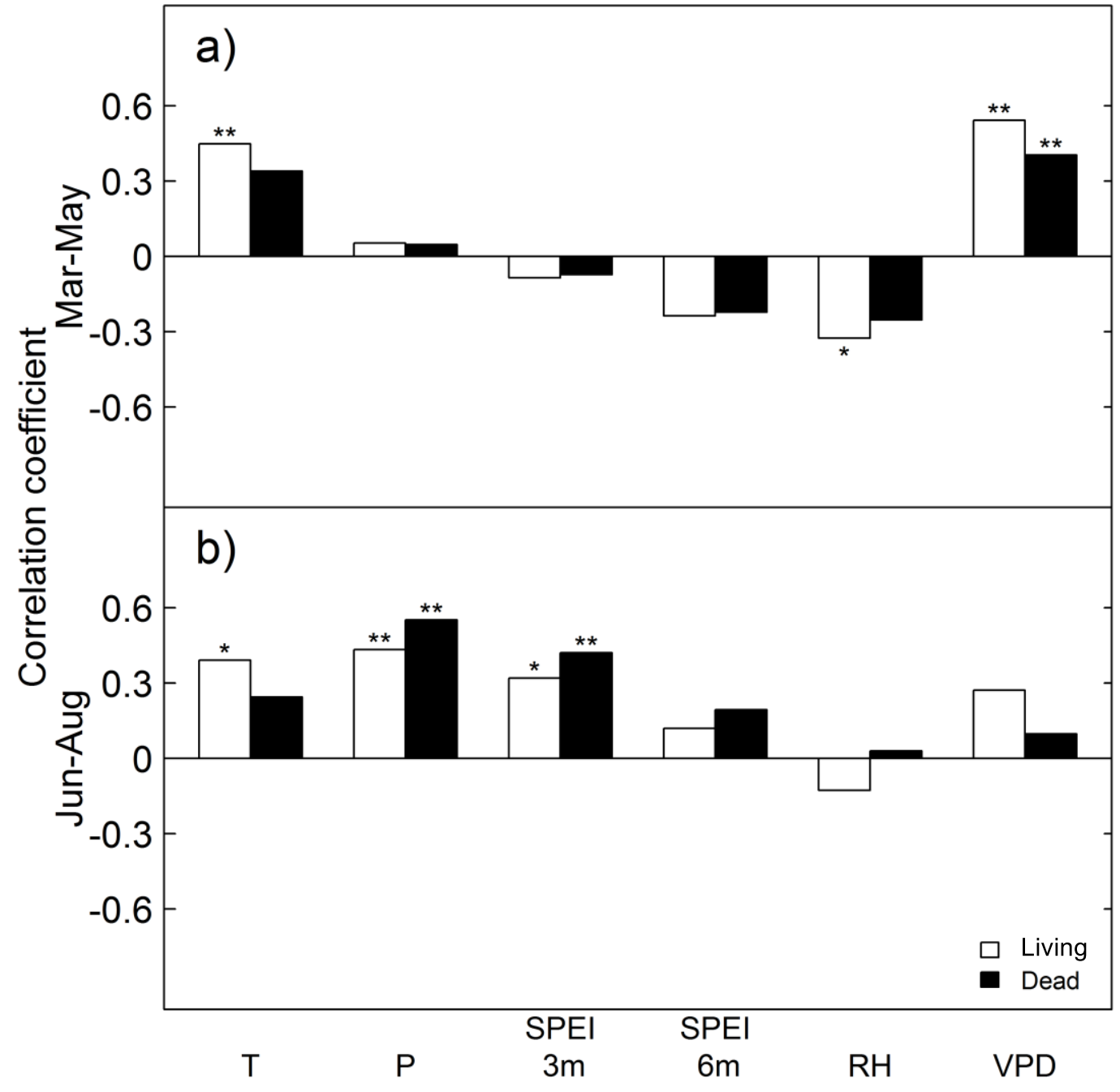

Figure 5. 


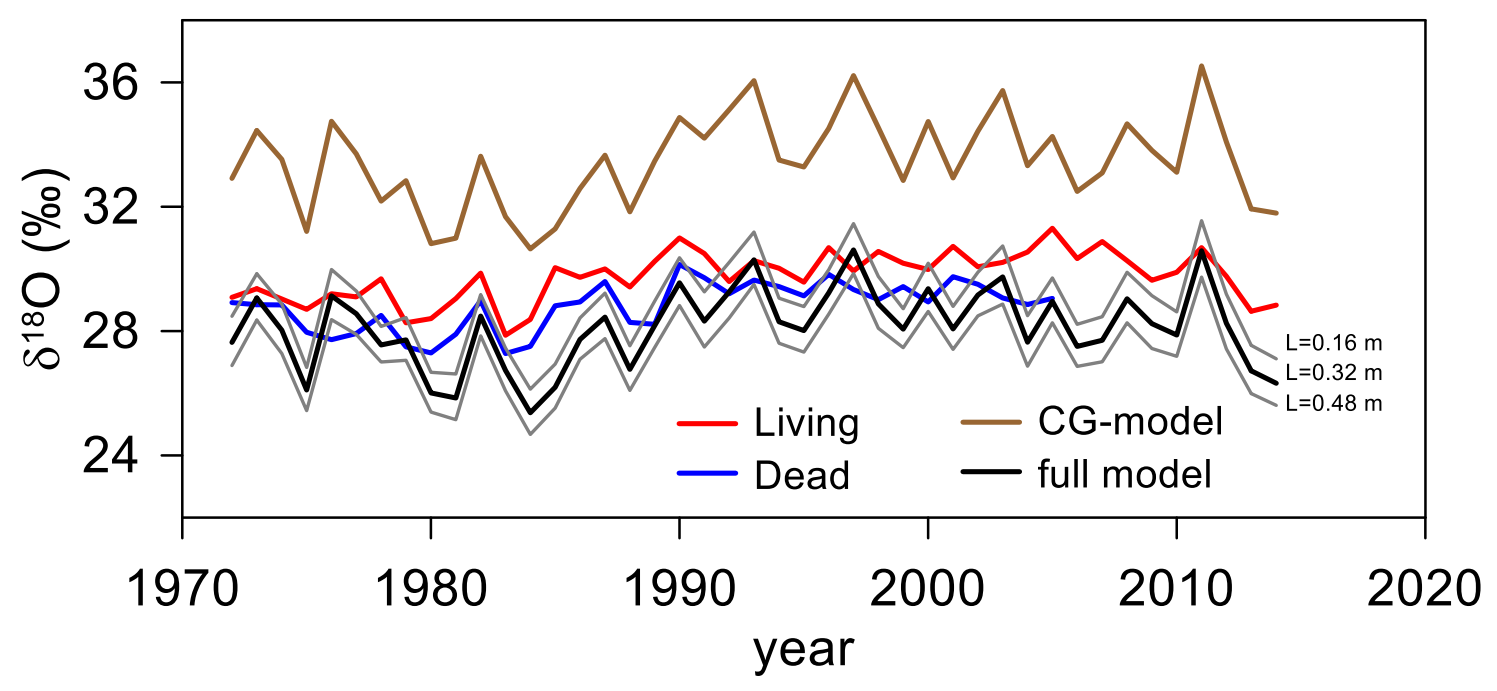

Figure 6. 